\title{
Assessment of groundwater quality of Ballia district, Uttar Pradesh, India, with reference to arsenic contamination using multivariate statistical analysis
}

\author{
Asha Lata Singh ${ }^{1} \cdot$ Vipin Kumar Singh ${ }^{1}$
}

Received: 6 January 2017 / Accepted: 25 May 2018 / Published online: 6 June 2018

(c) The Author(s) 2018

\begin{abstract}
A total of 22 water quality parameters were selected for the analysis of groundwater samples with reference to arsenic contamination. Samples were collected in the pre-monsoon and monsoon seasons of the year 2013. The maximum arsenic concentration in both the pre-monsoon and monsoon seasons was approximately the same, i.e., the maximum arsenic concentration being 75.60 and $74.46 \mu \mathrm{g} / \mathrm{L}$ in pre-monsoon and monsoon, respectively. Out of 72 collected samples, three were below the WHO guideline value of $10 \mu \mathrm{g} / \mathrm{L}$ for arsenic concentration. In $95.83 \%$ of the groundwater samples, the arsenic concentration was above the permissible limit. Nickel, manganese, and chromium concentrations were above the permissible limits in nearly all samples except for chromium concentration in a few pre-monsoon samples. However, the total iron concentrations in 23 samples (31.94\%) were above the permissible limit. A total of six and seven principal components (PCs) were extracted using principal component analysis during the pre-monsoon and monsoon seasons, respectively, accounting for 76.25 and $78.52 \%$ of the total variation during two consecutive seasons. Correlation statistics revealed that the arsenic concentration was positively correlated with phosphate, iron, ammonium, bicarbonate, and manganese concentrations but negatively correlated with oxidation reduction potential (ORP), sulfate concentration, electrical conductivity, and total dissolved solids concentration. The negative correlation of arsenic with ORP suggested reducing conditions prevailing in the groundwater. The trilinear Piper diagram revealed calcium and magnesium enrichment of groundwater with an abundance of chloride ions but no predominance of bicarbonate ions. Thus, the groundwater fell into $\mathrm{Ca}^{2+}-\mathrm{Mg}^{2+}-\mathrm{Cl}^{-}-\mathrm{SO}_{4}{ }^{2-}$ category.
\end{abstract}

Keywords Groundwater · Arsenic contamination · Oxidation reduction potential · Piper diagram

\section{Introduction}

Groundwater is among the most important natural resources available on earth. It is the primary valuable source of drinking water for humankind. Since there is not sufficient surface water to fulfill the ever growing demand for clean drinking water, use of groundwater cannot be avoided. Further, surface water is more vulnerable to contamination than groundwater. Due to rapid industrialization and population growth worldwide, groundwater utilization has increased very rapidly in the past decades. Groundwater is being extensively utilized in industry, agriculture, drinking water supply,

Vipin Kumar Singh

vipinks85@gmail.com

1 Department of Botany, Banaras Hindu University, Varanasi 221005, India and daily routine human activities. Overuse of groundwater resources has not only deteriorated the quality of water but also made it susceptible to various contaminants. Water table in some parts is lowering rapidly which will soon reach to an alarming situation. Therefore, available groundwater resources need to be used in a sustainable way by the present generation.

Today, groundwater pollution has emerged as an environmental challenge for new generation (Vodela et al. 1997). Clean potable water is essential to almost all living organisms. Millions of human deaths have already been claimed by the consumption of contaminated water. Waterborne diseases are spreading very rapidly due to the leaching of undesirable substances into groundwater and improper sanitary conditions. Due to diseases associated with the consumption of polluted groundwater caused by insufficient cleanliness, the United Nations has declared clean water and sanitation as basic human rights (UN 2006). 
Both natural processes and human activities are responsible for the deterioration of the groundwater quality (Andrade et al. 2008; Kouras et al. 2007; Gu et al. 2017). Anthropogenic activities such as rapid industrialization, excessive use of phosphate fertilizers, pesticides, herbicides, domestic effluents, and over utilization of groundwater have caused the placement of a large quantity of unwanted contaminants into groundwater and surface water (Singh et al. 2004; Devic et al. 2014; Selvakumar et al. 2017). Thus, anthropogenic activities are important drivers of both surface and groundwater pollution (Niemi et al. 1990; Ayotte et al. 2011). Among the contaminants, heavy metals and metalloid pose a serious threat to human health. The concentration of the metalloid arsenic has risen above the concentration limits set for groundwaters of many countries including Punjab (Sharma et al. 2016), Jharkhand (Alam et al. 2016; Chakraborty 2015), Manipur (Chandrashekhar et al. 2016), Mizoram (Blick et al. 2016), Arunachal Pradesh (Shah 2015), Andhra Pradesh (Hussain and Rao 2014), Assam (Das et al. 2017), Himachal Pradesh (Rana et al. 2016), Telangana (Purushotham et al. 2017), Chhattisgarh (Patel et al. 2017; Singhal et al. 2018), Uttar Pradesh (Shah 2017; Kumar et al. 2017a, b; Olea et al. 2018), Bihar (Chakraborti et al. 2016), and West Bengal in India (Smedley and Kinniburgh 2002; Rahman et al. 2009; Shrivastava et al. 2017; Bhowmick et al. 2018). Thus, the assessment of groundwater quality with respect to the concentration of $\mathrm{NO}_{3}{ }^{-}, \mathrm{PO}_{4}{ }^{3-} \mathrm{SO}_{4}{ }^{2-}, \mathrm{NH}_{4}{ }^{+}$, $\mathrm{Cl}^{-}$ions and heavy metals and semimetals such as $\mathrm{Cu}, \mathrm{Cr}$, $\mathrm{Co}, \mathrm{Ni}$ and $\mathrm{As}$ is very important and necessary. Groundwater and surface water quality can be assessed very effectively by employing statistical tools such as univariate (mean, minimum, maximum and standard deviation), bivariate (correlation), and multivariate analysis (principal component analysis, cluster analysis, and factor analysis) (Omo-Irabor et al. 2008; Kazi et al. 2009; Zhao et al. 2011; Ravikumar and Somashekar 2017; Yidana et al. 2018). Generally, data fitness for principal component analysis and factor analysis is performed by means of KMO (Kaiser-Meyer-Olkin) and Bartlett's sphericity test (Zhao et al. 2011; Singh et al. 2013). Ward's method of cluster analysis using squared Euclidean distance (Fovell and Fovell 1993) was performed for clustering. The Piper diagram has also been applied widely to find out the characteristics of any water system.

The objective of the present paper is to analyze the groundwater quality of two different blocks (Reoti and Belahari) of the Ballia district, Uttar Pradesh, India, with emphasis on arsenic distribution and contamination. So far, very limited reports on groundwater quality of this district using multivariate statistical tools are available.

\section{Sampling site}

The Ballia district is situated in the eastern part of the state Uttar Pradesh, India, and is part of the central Ganga plain. The north latitude and east longitude are $25^{\circ} 23^{\prime \prime}$ to $26^{\circ} 11^{\prime \prime}$ and $83^{\circ} 38^{\prime \prime}$ to $84^{\circ} 39^{\prime \prime}$, respectively. Its total geographical area is $3168 \mathrm{~km}^{2}$ supporting a population of 2.75 million. The district has been divided into six tehsils and seventeen blocks. Chhoti Saraju, Ghaghra, and Ganga are the rivers that flow through the district (Ali et al. 2012; Chauhan et al. 2009). According to reports of Tripathi (2007-2008), old and younger alluvium constitutes the major physiography of district. The climate of the district is sub-humid supporting grassland vegetation. The maximum temperature was reached in May $\left(32.25{ }^{\circ} \mathrm{C}\right)$ followed by June $\left(30.75{ }^{\circ} \mathrm{C}\right)$. The minimum recorded temperature is $12.15^{\circ} \mathrm{C}$ during December followed by $15.9^{\circ} \mathrm{C}$ during January. The highest and lowest humidity has been recorded in August (82.5\%) and September (80\%), respectively. The average rainfall in the district is $983 \mathrm{~mm}$. The Reoti and Belahari blocks (area $140 \mathrm{~km}^{2}$ and population 0.1 million) are the sites of study for the groundwater quality characteristics.

\section{Materials and methods}

\section{Sample collection and analysis}

A total of 72 samples from hand pumps were collected into pre-washed and acidified polyethylene bottles of $300 \mathrm{ml}$ capacity. Before sampling, the hand pumps were driven for 5-10 min to flush out stored water. Samples were collected in two sets from each site. One set contained no preservative and was used for the anions analysis. The other set of sample was treated with $\mathrm{HCl}(1 \mathrm{ml}$ per 500 sample $)$ and used for the analysis of heavy metals like iron, manganese, copper, chromium, cobalt, and metalloid arsenic. Before analysis, all samples were stored at $4{ }^{\circ} \mathrm{C}$ in a refrigerator. Some parameters like temperature, $\mathrm{pH}$, electrical conductivity (EC), oxidation-reduction potential (ORP), and total dissolved solids (TDS) were determined on site using a portable water analysis kit (Decibel Dynamics Ltd., New Delhi, India).

Water samples were digested with a diacid mixture made up of nitric acid and perchloric acids in the ratio 10:1. Equal volume of samples and diacid mixture were mixed properly and evaporated on a hot plate till no turbidity and color appeared in the solution. Finally, the volume was adjusted to that of the original sample volume by adding Milli-Q water and analyzed for the desired metal. The metal and metalloid (arsenic) concentrations were determined using a PerkinElmer AAnalyst 800 Atomic Absorption Spectrophotometer 
(AAS). Flame method of AAS was applied to determine the concentration of metals.

The concentration of total arsenic in sample was analyzed by a Hydride Generation-Atomic Absorption Spectrophotometer (HG-AAS) equipped with the instrument. Before analysis, all samples were treated with potassium iodide and ascorbic acid to reduce any arsenate(As V) to arsenite(III). The detection limit for arsenic was $1 \mu \mathrm{g} / \mathrm{L}$.

The concentrations of phosphate, nitrate, nitrite, ammonium, chloride, sulfate and bicarbonate were determined by standard methods.

Sodium adsorption ratio (SAR) and percent sodium were calculated according to a formula used by Subba Rao (2006), Singh et al. (2013), Sharma et al. (2018), and RamyaPriya and Elango (2018). All cation concentrations are expressed as meq $\mathrm{L}^{-1}$.

$$
\begin{aligned}
& \mathrm{SAR}=\mathrm{Na}^{+} /\left[\left(\mathrm{Ca}^{2+}+\mathrm{Mg}^{2+}\right) / 2\right]^{0.5} \\
& \% \mathrm{Na}=\left(\mathrm{Na}^{+}+\mathrm{K}^{+}\right) 100 /\left(\mathrm{Ca}^{2+}+\mathrm{Mg}^{2+}+\mathrm{Na}^{+}+\mathrm{K}^{+}\right)
\end{aligned}
$$

Pearson's correlation coefficient was calculated using Microsoft Office Excel 2007, while principal component analysis, factor analysis, and cluster analysis were computed using SPSS 16. A Piper diagram was generated using GW chart software (Tables 1, 2 and 3).

\section{Multivariate statistical analysis}

Prior to factor analysis, data appropriateness was checked by $\mathrm{KMO}$ and Bartlett's sphericity test. Multivariate analysis is an important statistical method which can easily be used to identify the factors governing the quality of a water system and help us to manage (regulate) those factors very strictly to minimize contamination (Reghunath et al. 2002; Simeonov et al. 2004). Multivariate statistics such as principal component analysis, factor analysis, and cluster analysis have been used for the assessment of surface water quality (Yidana 2010; Noori et al. 2010; Shrestha and Kazama 2007; Zhao et al. 2011; Singh et al. 2018; Kashyap et al. 2018). Kazi et al. (2009) applied this tool for the quality determination of a polluted lake ecosystem.

Principal component analysis (PCA) is a method of dimension reduction. Here, a large number of factors are minimized in such a way that the resulting smaller factor represents maximum variance of data. Generally, PCA transforms a large number highly correlated variables to small uncorrelated variables, i.e., principal components (PCs) representing most of the variation in the data (Singh et al. 2005; Shrestha and Kazama 2007; Kouras et al. 2007). After extraction, minor principal components (PCs) showing very little contribution to data variation are eliminated (Yeung 1999) so that data can be represented in its original form with a minimum loss of information (Helena et al. 2000; Vega et al. 1998).

Hierarchical agglomerative cluster analysis (HACA), the most common clustering method, groups the samples according to their level of similarity or dissimilarity. The most similar objects are grouped first followed by higher clustering at a consecutive stage. The result is represented in the form of a dendrogram. The purpose of cluster analysis lies in the determination of distinct patterns within multivariate data (McKenna 2003; Kumar et al. 2018). Ward's method using squared Euclidean distance is considered to be the most appropriate method for dendrogram preparation (Kotti et al. 2005; Gulgundi and Shetty 2018).

Range, mean, maximum, minimum, and standard deviation are the tools of univariate descriptive statistics (OmoIrabor et al. 2008; Thapa et al. 2018).

\section{Results and discussions}

\section{Physicochemical characteristics}

Water quality analyses of 72 groundwater samples collected during the pre-monsoon and monsoon season are represented in table (quote the table number). The mean temperature of groundwater did not vary much, i.e., the mean being 26.31 and $26.34{ }^{\circ} \mathrm{C}$ during the pre-monsoon and monsoon seasons, respectively. The groundwater samples showed a $\mathrm{pH}$ variation from mild acidic to near neutral. The mean $\mathrm{pH}$ varied from 6.58 to 6.78 in the pre-monsoon and monsoon samples, respectively (Figs. 1, 2, 3, 4, 5, 6 and 7).

Electrical conductivity varied from 0.32 to $1.06 \mathrm{mS} /$ $\mathrm{cm}$ (mean value 0.56 ) in the pre-monsoon and $0.35 \mathrm{mS} / \mathrm{cm}$ to $1.32 \mathrm{mS} / \mathrm{cm}$ (mean 0.71 ) in the monsoon samples. The higher conductivity during the monsoon season is probably due to the leaching of minerals. The ORP value falls in the range $-147 \mathrm{mv}$ to $144 \mathrm{mv}$ (mean -45.08 ) and -142 $\mathrm{mv}$ to $-42 \mathrm{mv}$ (mean - 76.81) in the pre-monsoon and monsoon samples, respectively. The negative mean value of ORP indicates reducing groundwater conditions which are responsible for the dissolution of arsenic-bearing minerals. All water samples are within the prescribed limits for total dissolved solids concentration. US-EPA has set the permissible limit of TDS in drinking water as $500 \mathrm{mg} / \mathrm{L}$. The sulfate concentration ranged from 1.06 to $37.54 \mathrm{mg} / \mathrm{L}$ (mean 7.98) and 1.06 to 10.76 (mean 4.38 ) $\mathrm{mg} / \mathrm{L}$ in the premonsoon and monsoon samples, respectively. The phosphate concentrations varied from 1.19 to 2.55 (mean 1.75) and 0.83 to 5.71 (mean 2.60) in the pre-monsoon and monsoon samples, respectively. However, the concentration of sulfate and phosphate is within the prescribed permissible limits of WHO. The permissible limit of sulfate and phosphate in groundwater is 500 and $5 \mathrm{mg} / \mathrm{L}$, respectively. The mean

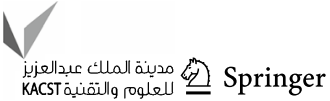




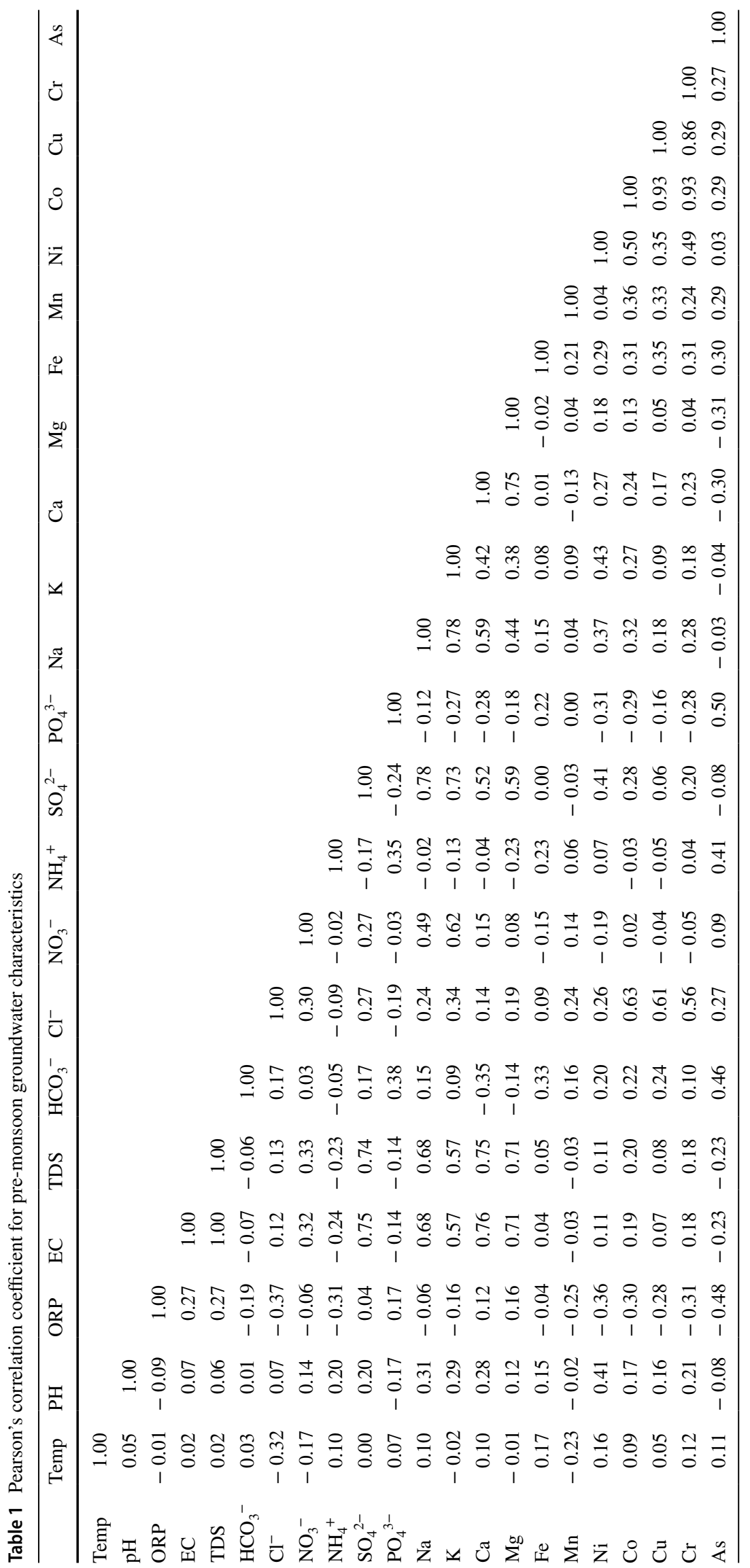




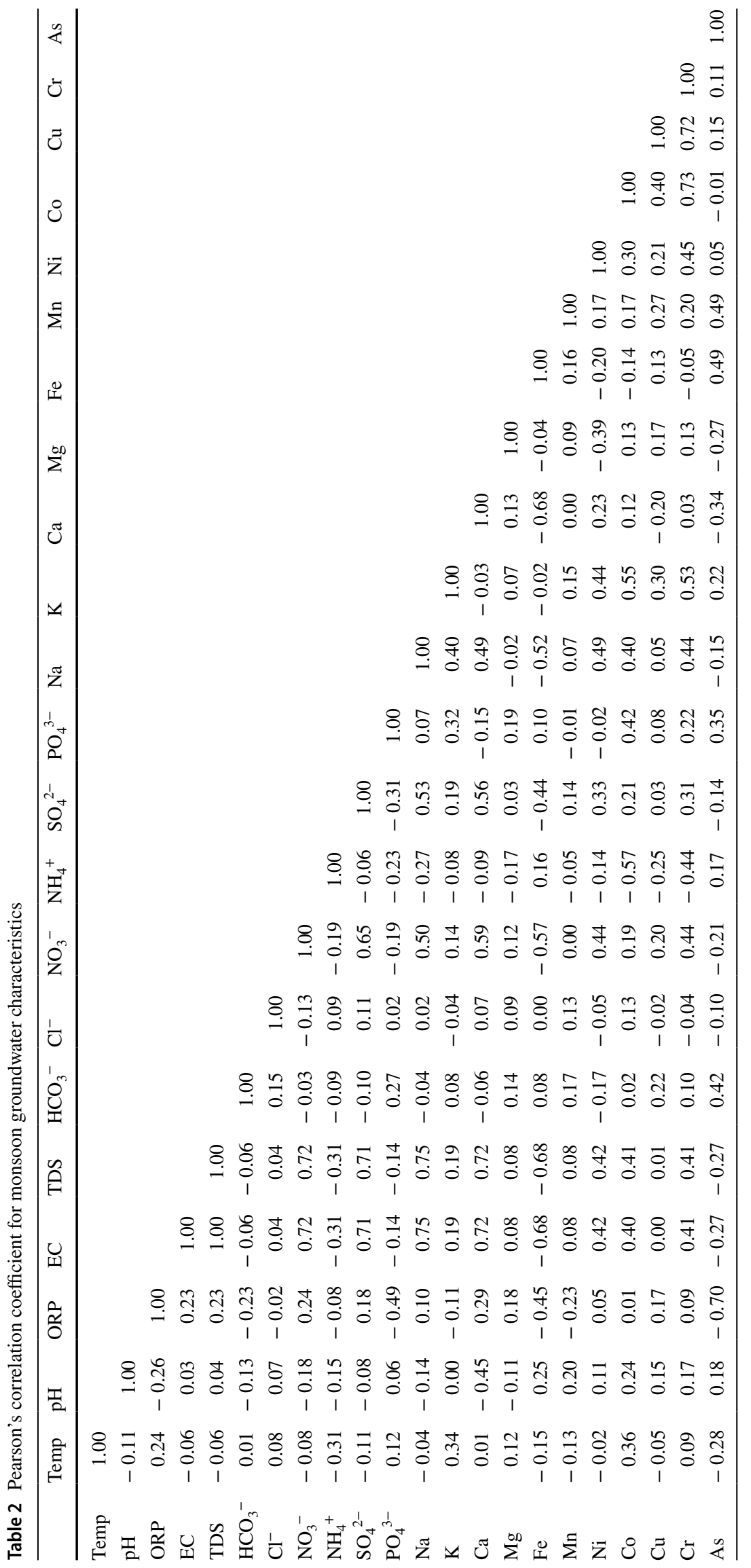


Table 3 Major water quality characteristics, abbreviations, units and determination methods

Fig. 1 Scree plots of the eigenvalues from PCA during the pre-monsoon season

\begin{tabular}{llll}
\hline Parameters & Abbreviations & $\mathrm{Units}$ & Analytical methods \\
\hline Temperature & $\mathrm{Temp}$ & ${ }^{\circ} \mathrm{C}$ & Mercury thermometer \\
$\mathrm{pH}$ & $\mathrm{pH}$ & $\mathrm{pH}$ unit & $\mathrm{pH}$ meter \\
Oxidation reduction potential & $\mathrm{ORP}$ & $\mathrm{mV}$ & $\mathrm{pH}$ meter \\
Electrical conductivity & $\mathrm{EC}$ & $\mathrm{mS} / \mathrm{cm}$ & $\mathrm{EC}$ probe \\
Total dissolved solids & $\mathrm{TDS}$ & $\mathrm{mg} / \mathrm{L}$ & TDS probe \\
Bicarbonate & $\mathrm{HCO}_{3}{ }^{-}$ & $\mathrm{mg} / \mathrm{L}$ & Titrimetric \\
Chloride & $\mathrm{Cl}^{-}$ & $\mathrm{mg} / \mathrm{L}$ & Titrimetric \\
Nitrate & $\mathrm{NO}_{3}{ }^{-}$ & $\mathrm{mg} / \mathrm{L}$ & Spectrophotometric \\
Ammonium & $\mathrm{NH}_{4}{ }^{+}$ & $\mathrm{mg} / \mathrm{L}$ & Spectrophotometric \\
Sulfate & $\mathrm{SO}_{4}{ }^{2-}$ & $\mathrm{mg} / \mathrm{L}$ & Spectrophotometric \\
Phosphate & $\mathrm{PO}_{4}{ }^{3-}$ & $\mathrm{mg} / \mathrm{L}$ & Spectrophotometric \\
Sodium & $\mathrm{Na}$ & $\mathrm{mg} / \mathrm{L}$ & Flame AAS \\
Potassium & $\mathrm{K}_{\text {Calcium }}$ & $\mathrm{mg} / \mathrm{L}$ & Flame AAS \\
Magnesium & $\mathrm{Ca}$ & $\mathrm{mg} / \mathrm{L}$ & Flame AAS \\
Iron & $\mathrm{Mg}$ & $\mathrm{mg} / \mathrm{L}$ & Flame AAS \\
Manganese & $\mathrm{Fe}$ & $\mathrm{mg} / \mathrm{L}$ & Flame AAS \\
Nickel & $\mathrm{Mn}$ & $\mathrm{mg} / \mathrm{L}$ & Flame AAS \\
Cobalt & $\mathrm{Ni}$ & $\mathrm{mg} / \mathrm{L}$ & Flame AAS \\
Copper & $\mathrm{Co}$ & $\mathrm{mg} / \mathrm{L}$ & Flame AAS \\
Chromium & $\mathrm{Cu}$ & $\mathrm{mg} / \mathrm{L}$ & Flame AAS \\
Arsenic & $\mathrm{Cr}$ & $\mathrm{mg} / \mathrm{L}$ & Flame AAS \\
\hline & $\mathrm{As}$ & $\mu \mathrm{g} / \mathrm{L}$ & Hydride generation AAS \\
\hline
\end{tabular}

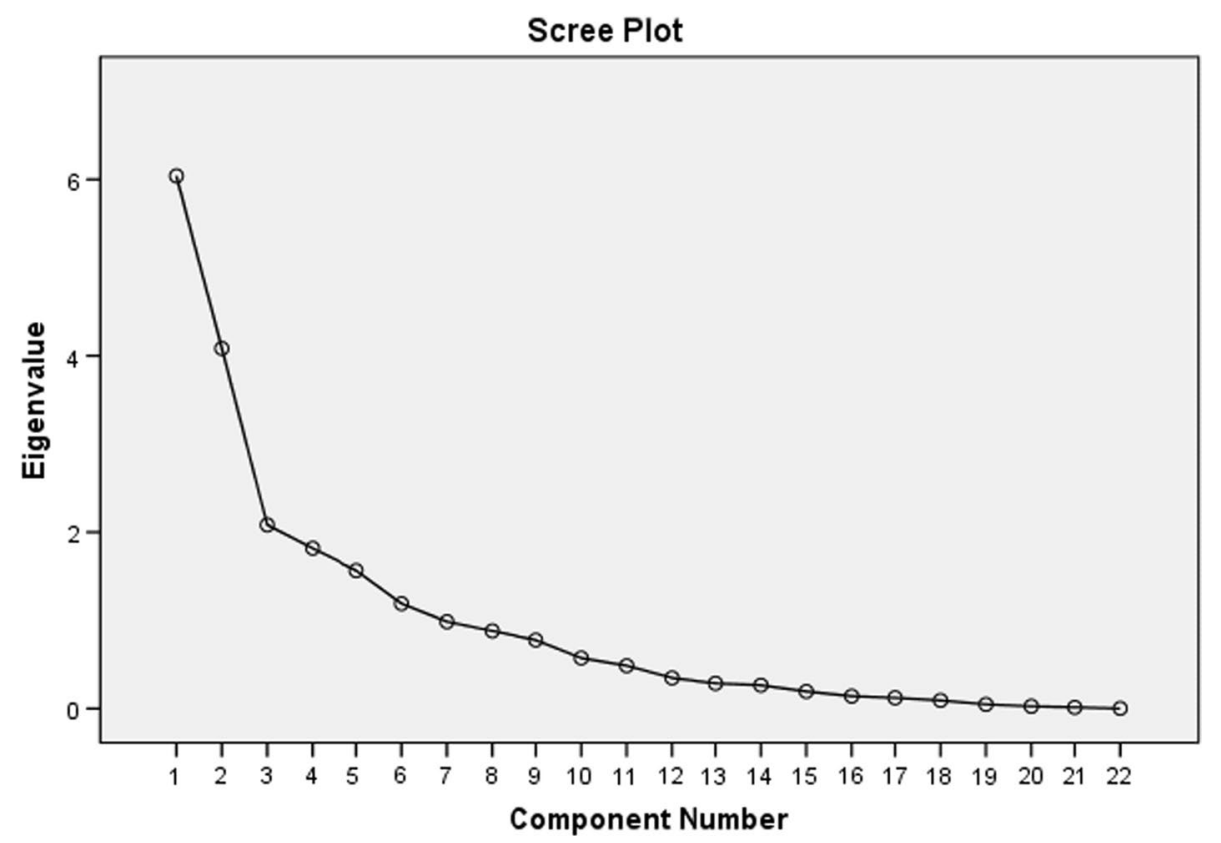

chloride concentration is below the WHO recommended limit of $250 \mathrm{mg} / \mathrm{L}$ in both the pre-monsoon and monsoon samples. Nickel, manganese, and chromium concentrations were found to be above the permissible limit in nearly all samples except a few samples from the pre-monsoon season for chromium. Copper concentrations varied from 1.41 to $5.87 \mathrm{mg} / \mathrm{L}$ and 5.32 to $7.35 \mathrm{mg} / \mathrm{L}$ during the pre-monsoon and monsoon seasons, respectively. WHO has recommended copper concentration in drinking water below $1.00 \mathrm{mg} / \mathrm{L}$. The arsenic concentrations in the groundwater samples were 
Fig. 2 Scree plots of the eigenvalues from PCA during the monsoon season

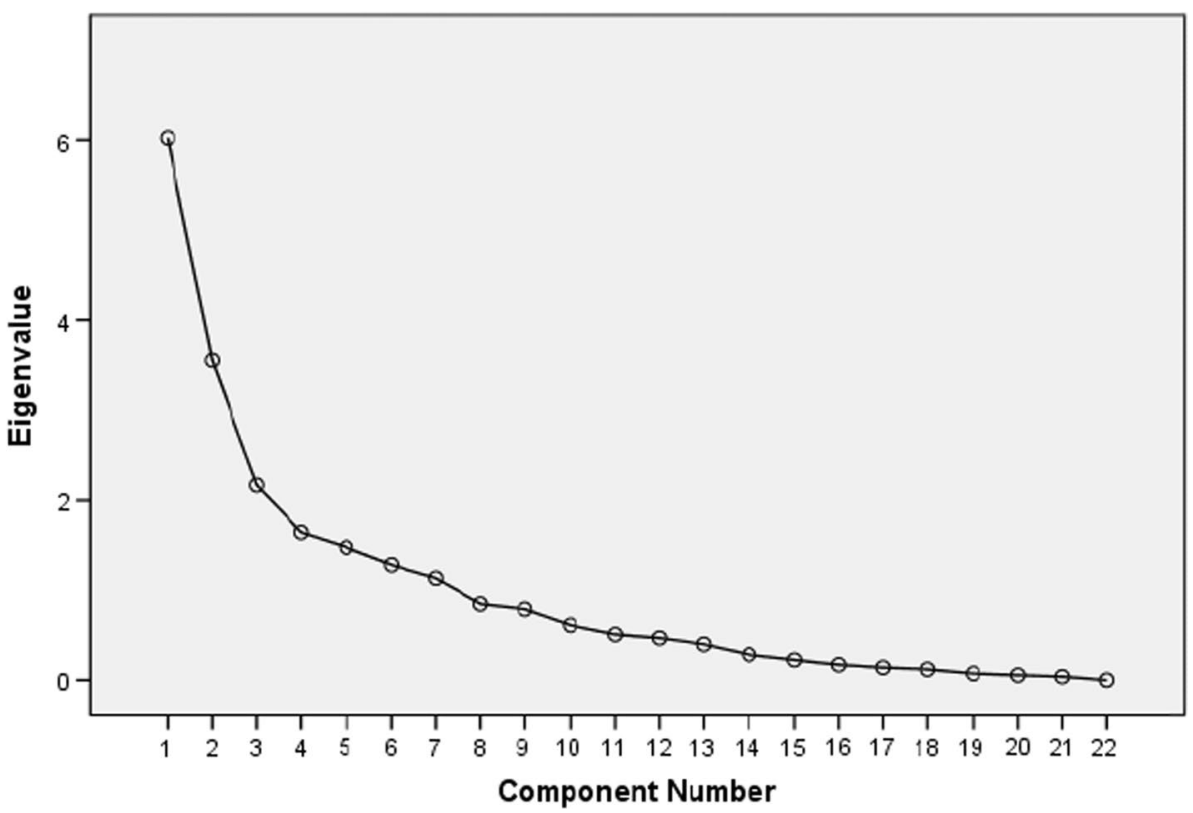

Dendrogram using Ward Method

of pre-monsoon data

found to be in the range 4.18 to $75.60 \mu \mathrm{g} / \mathrm{L}$ (mean 24.67) and 0.34 to $74.46 \mu \mathrm{g} / \mathrm{L}$ (27.81) during the pre-monsoon and monsoon seasons, respectively. Sixty-nine samples showed arsenic concentrations above the permissible limit defined by WHO. The maximum arsenic concentration was $75.62 \mu \mathrm{g} / \mathrm{L}$, and the concentration was approximately same in both the pre-monsoon and monsoon seasons.

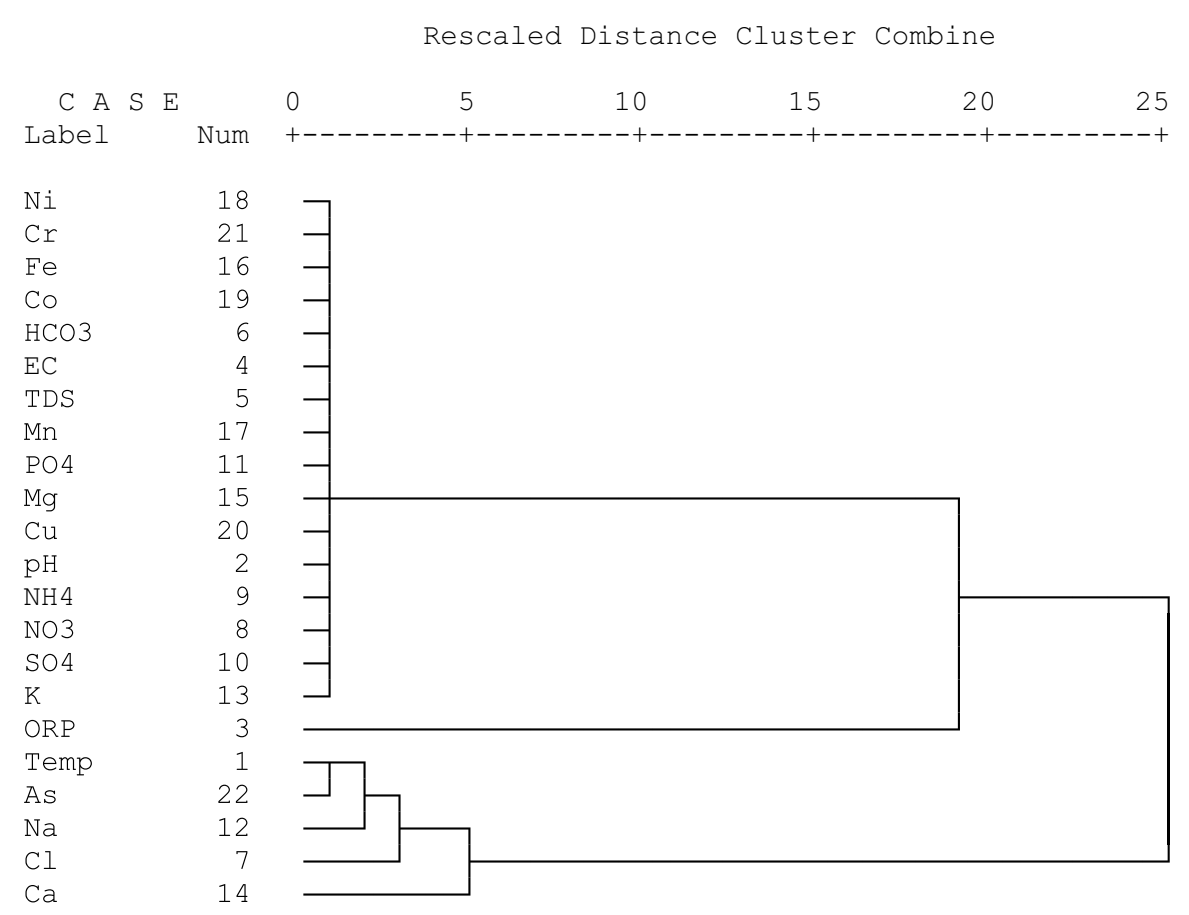

\section{Groundwater hydrochemical facies}

The trilinear Piper diagram was prepared using the software GW chart. The diagram reveals very clearly the relative concentrations of major ions present in the groundwater samples collected. The diagram shows a combination of two triangles and a single diamond above the adjacent triangles in terms of anions like $\mathrm{Cl}^{-}, \mathrm{SO}_{4}{ }^{2-}, \mathrm{HCO}_{3}{ }^{-}, \mathrm{CO}_{3}{ }^{2-}$ and cations 
Fig. 4 Hierarchical dendrogram of monsoon data dendrogram using the Ward's method
Dendrogram using Ward Method

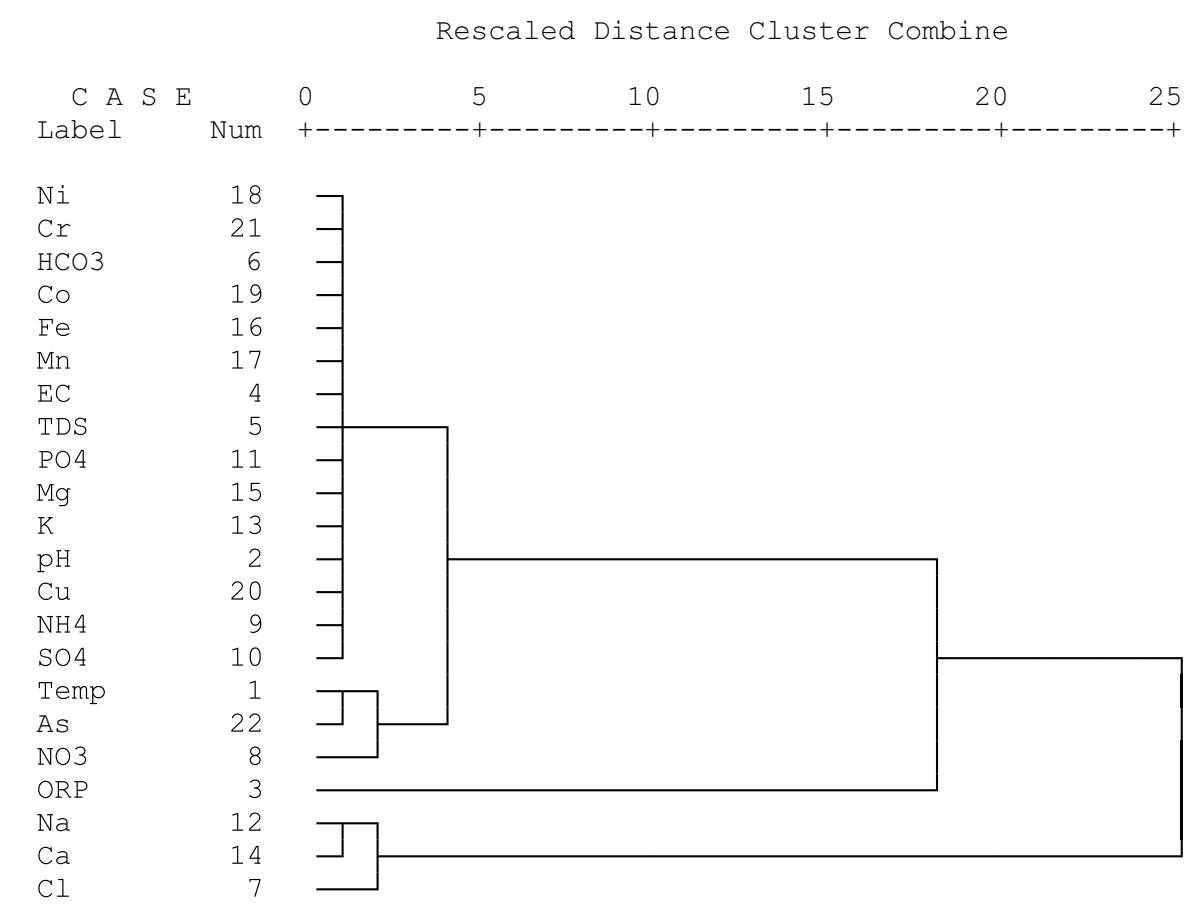

Fig. 5 Rotated loading plots of first three PCs in a pre-monsoon and $\mathbf{b}$ monsoon seasons
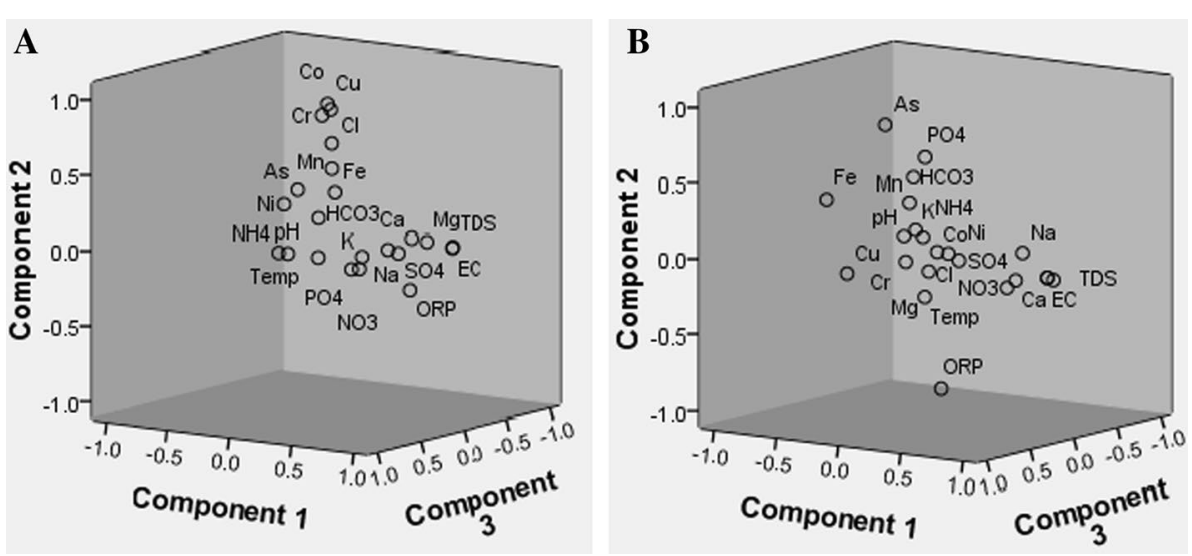

like $\mathrm{Na}^{+}, \mathrm{K}^{+}, \mathrm{Ca}^{2+}$ and $\mathrm{Mg}^{2+}$. The left triangle shows major cation concentrations and the right one major anion concentration. The collected groundwater samples collected show the major composition as a $\mathrm{Ca}^{2+}-\mathrm{Mg}^{2+}-\mathrm{Cl}^{-}-\mathrm{SO}_{4}{ }^{2-}$ type, calcium type, no dominant type, calcium chloride type and chloride type. $\mathrm{Ca}^{2+}-\mathrm{Mg}^{2+}-\mathrm{Cl}^{-}-\mathrm{SO}_{4}{ }^{2-}$-type composition of groundwater has been reported previously (Laluraj et al. 2006; Ravikumar et al. 2010; Dar et al. 2011; Jasmin and Mallikarjuna 2006; Yadav et al. 2018; Aher 2017). Calcium chloride-type water may be produced by either reverse ion exchange between sodium and calcium (Adams et al. 2001; Sappa et al. 2014; Kumar et al. 2017a, b) or mixing of freshwater and older saline water (Adams et al. 2001). According to Chebotarev's sequence, the chloride concentration of water increases along groundwater flow from recharge zone to discharge zone (Yakubo et al. 2009). The presence of chloride-type water indicates its withdrawal from very deep strata, i.e., a discharge zone in groundwater. Chloridetype dominated water has recently been reported (Chitradevi and Sridhar 2011; Kshetrimayum and Bajpai 2012). The presence of chloride in groundwater results from weathering of rock materials, industrial effluents, domestic effluents (Karanth 1987; Srinivas et al. 2017), and leaching of chloride-based pesticides applied to agro-ecosystems. The Piper diagram shown here is similar to that presented by Saleh et al. (1999). Analysis of the Piper diagram reveals that groundwater samples from the Reoti and Belhari blocks are very similar in origin. 
Fig. 6 Piper diagram of groundwater samples during pre-monsoon and monsoon season

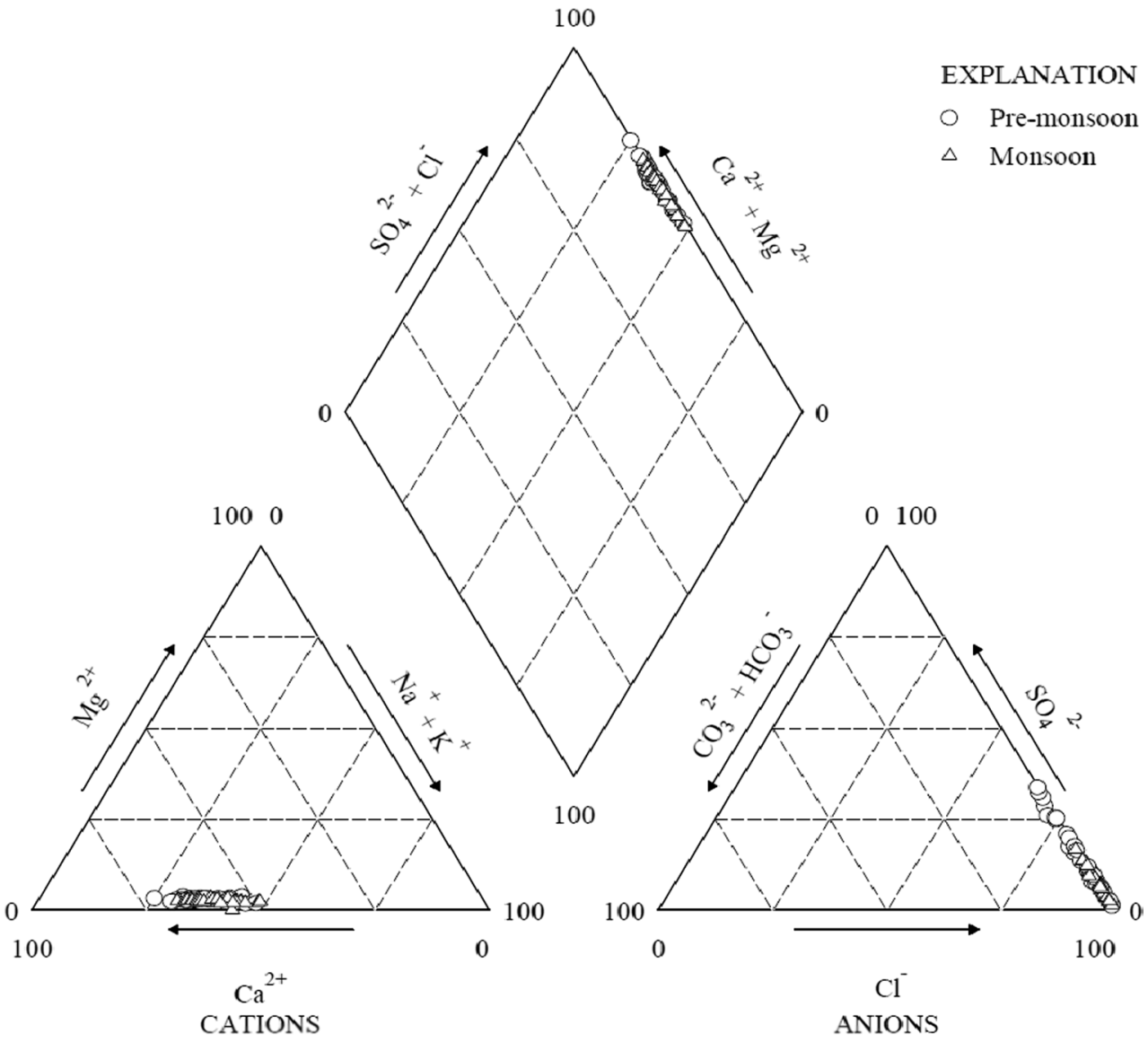

\section{Groundwater quality criteria of for irrigation purpose}

All groundwater samples have total dissolved solids concentrations under the satisfactory water class. With respect to salinity hazard, it can be concluded that more than $85 \%$ samples are good for irrigation during the pre-monsoon season. But, in the monsoon season, approximately $64 \%$ of the samples are safe for irrigation purposes. Similarly, most of the samples have a sodium concentration $(20-40 \mathrm{mg} / \mathrm{L})$ below safety limits $(83.33 \%)$ during the pre-monsoon season, but, in the monsoon season, the Na concentration of only $58.33 \%$ of the samples is below a safe sodium level (20-40 mg/L). However, $16.67 \%$ of the pre-monsoon samples and $41.67 \%$ of the monsoon samples display sodium concentration in the range $40-60 \mathrm{mg} / \mathrm{L}$. Due to precipitation, there is a decline in groundwater quality in terms of both salinity hazard class and sodium level. It is interesting here to note that all groundwater samples are excellent with respect to sodium hazard level.

Sodium adsorption ratio (SAR) is defined as the ratio of sodium ion concentration to the square root of the average calcium and magnesium ion concentrations. Increased sodium adsorption ratio (SAR) of water not only affects the physical and chemical characteristics of soil but also negatively alters the useful activity (biological organic matter decomposition) associated with native soil microorganisms. Biochemical properties of soil are also disturbed to a greater extent. The ultimate results of groundwater irrigation with a high SAR value can be described in terms of soil degradation and low productivity (Rietz and Haynes 2003; Ahada and Suthar 2017; Sharma et al. 2018). Irrigation with water having higher SAR value increases the soil sodium concentration which leads to the destruction of soil structure and aggregates (Mavi et al. 2012; Srinivas et al. 2017; Selvaganapathi et al. 2017). A positive correlation between SAR and clay dispersion (Nelson et al. 1997) has already been reported.

In general, water with a high SAR value poses a great hazard to soil. All samples have a sodium adsorption ratio (SAR) in the range $0-10$. This shows the suitability of groundwater samples for irrigation. In conclusion, we can say that pre-monsoon groundwater samples are more suitable for agricultural irrigation than monsoon samples of groundwater. As $95.83 \%$ groundwater samples have an arsenic concentration above the WHO safer limit of $10 \mu \mathrm{g} / \mathrm{L}$, chances of arsenic poisoning in humans and animals through vegetables, cereal grains, and fodder (Das et al. 2004; Huq et al. 2006, Zhao et al. 2010; Chakraborti et al. 2014; Sharifi et al. 2017; Chandra et al. 2018) cannot be avoided. 


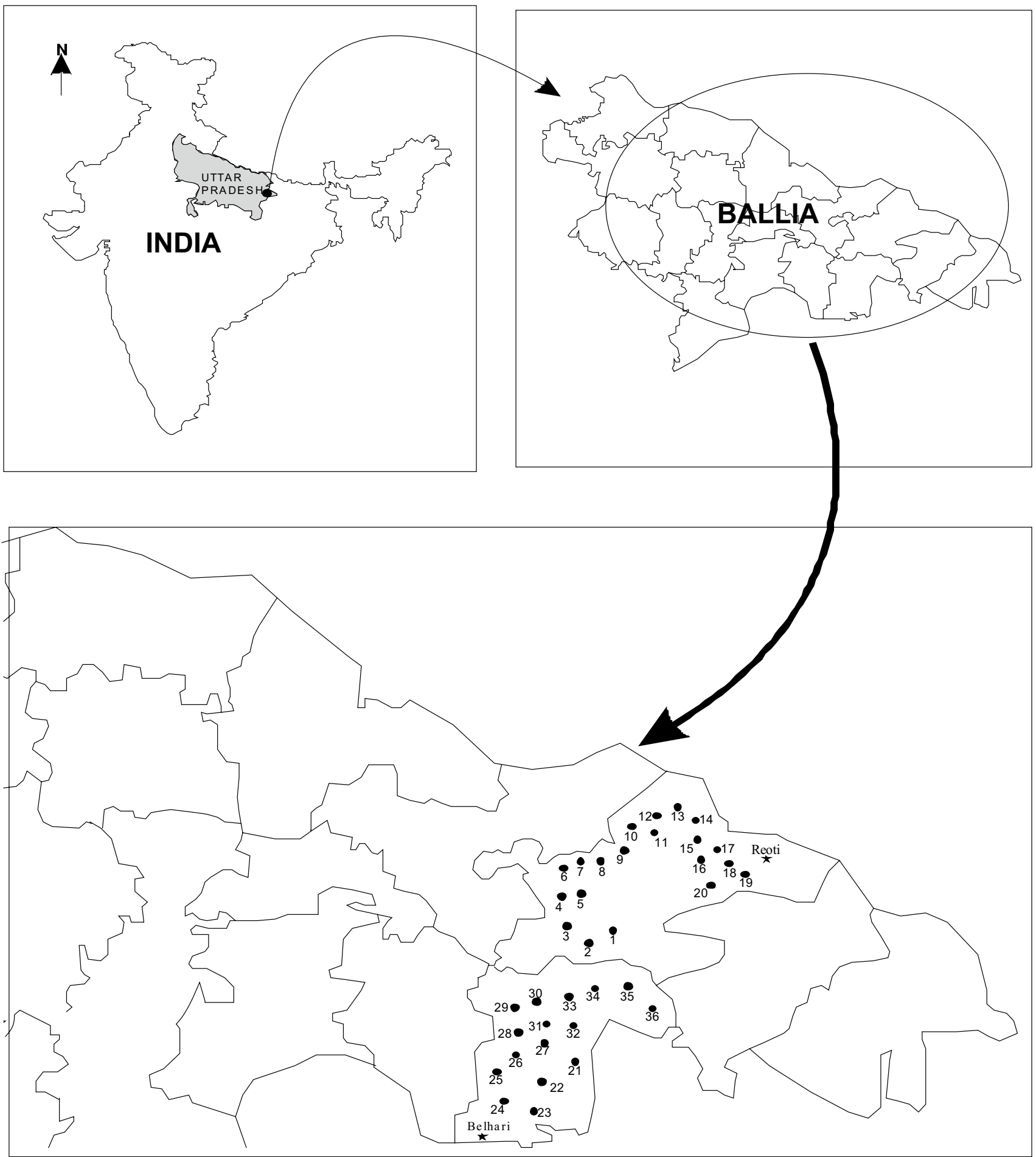

Fig. 7 Map showing sampling locations for groundwater

\section{Pearson's correlation statistics}

Arsenic concentration is negatively correlated with oxidation reduction potential (ORP) in both the pre-monsoon and monsoon samples indicating reducing groundwater conditions (Guo et al. 2010). A negative correlation of arsenic concentration with total dissolved solids concentration implies that arsenic may bind to surfaces available on solid substances. A negative correlation of arsenic concentration with sulfate supports the idea that it is mobilized under 
reducing groundwater conditions (Smedley and Kinniburgh 2002; Ohno et al. 2005). A weak negative correlation of arsenic concentration with sulfate concentration has been reported by Singh et al. (2013). Arsenic concentration is positively correlated with iron, manganese, copper, chromium, ammonium (Winkel et al. 2011), bicarbonate and phosphate concentrations (Winkel et al. 2011). A positive correlation of arsenic with iron, manganese, and bicarbonate in both pre-monsoon and monsoon samples indicates a geological origin for arsenic in groundwater (Kouras et al. 2007). Sulfate concentration is positively correlated with ORP, electrical conductivity, total dissolved solids, bicarbonate, chloride, and nitrate. Nitrate concentration is positively correlated with arsenic concentration in the pre-monsoon samples, while it is negatively correlated (Kanel et al. 2013) with arsenic concentration in monsoon samples. A positive correlation of arsenic concentration with iron, phosphate, and manganese concentration supports the idea of reductive dissolution of arsenic-bearing minerals and thus arsenic enrichment in groundwater (Naidu et al. 2006; Sathe et al. 2018; Kumarathilaka et al. 2018). A positive correlation of arsenic concentration with bicarbonate furthermore strengthens the idea that reducing conditions exist in the groundwater (McArthur et al. 2001). A positive correlation of arsenic concentration with bicarbonate and phosphate concentrations demonstrates a possible competitive displacement of phosphate and bicarbonate bound arsenic, thus favouring arsenic mobilization (Wang et al. 2009; Gao et al. 2013). Competitive binding of arsenate and phosphate ions onto an iron-based compound such as goethite has already been reported (Gao and Mucci 2001). It furthers unveils the fact that the application of phosphate-based fertilizers may also contribute to arsenic enrichment in groundwater (Acharyya et al. 1999, 2000; Chidambaram et al. 2017; Khanikar et al. 2017). But, it was suggested that the application of fertilizers may not be sufficient to be a primary source of phosphate (McArthur et al. 2001). Arsenic concentration is positively correlated with chloride concentration in the pre-monsoon samples but negatively correlated with chloride concentration. Chloride concentration is positively correlated with electrical conductivity, total dissolved solids, and bicarbonate concentrations. Iron concentration is positive correlated with ammonium and phosphate concentrations. Electrical conductivity is positively correlated with major ion concentrations such as sodium, potassium, calcium, magnesium, nitrate, and sulfate concentrations indicating the possibility of groundwater contamination due to natural weathering of carbonate-bearing minerals (Yadav et al. 2014; Sheikh et al.
Table 4 Characteristics of groundwater quality

\begin{tabular}{|c|c|c|c|c|c|c|c|c|}
\hline \multirow[t]{2}{*}{ Variable } & \multicolumn{4}{|c|}{ Pre-monsoon season } & \multicolumn{4}{|c|}{ Monsoon season } \\
\hline & Min & Max & Mean & SD & Min. & Max. & Mean & SD \\
\hline Temp & 24.10 & 28.30 & 26.31 & 1.36 & 23.90 & 29.10 & 26.34 & 1.50 \\
\hline $\mathrm{pH}$ & 6.05 & 6.97 & 6.58 & 0.28 & 6.34 & 7.06 & 6.78 & 0.20 \\
\hline ORP & -147.00 & 144.00 & -45.08 & 59.79 & -142.00 & -12.00 & -76.81 & 43.48 \\
\hline $\mathrm{EC}$ & 0.32 & 1.06 & 0.56 & 0.18 & 0.35 & 1.32 & 0.71 & 0.20 \\
\hline TDS & 0.20 & 0.67 & 0.36 & 0.12 & 0.22 & 0.85 & 0.46 & 0.13 \\
\hline $\mathrm{HCO}_{3}^{-}$ & 0.11 & 0.51 & 0.28 & 0.11 & 0.11 & 0.43 & 0.26 & 0.09 \\
\hline $\mathrm{Cl}^{-}$ & 3.76 & 114.37 & 45.35 & 30.66 & 18.37 & 151.24 & 58.15 & 30.80 \\
\hline $\mathrm{NO}_{3}^{-}$ & 6.61 & 29.42 & 9.35 & 3.72 & 6.05 & 105.88 & 18.08 & 23.78 \\
\hline $\mathrm{NH}_{4}^{+}$ & 0.52 & 15.31 & 6.39 & 3.76 & 0.52 & 9.53 & 4.71 & 2.53 \\
\hline $\mathrm{SO}_{4}^{2-}$ & 1.06 & 37.54 & 7.98 & 7.48 & 1.06 & 10.76 & 4.38 & 2.66 \\
\hline $\mathrm{PO}_{4}{ }^{3-}$ & 1.19 & 2.55 & 1.75 & 0.38 & 0.83 & 5.71 & 2.60 & 1.29 \\
\hline $\mathrm{Na}$ & 27.80 & 75.70 & 45.29 & 9.58 & 42.00 & 92.40 & 60.91 & 15.43 \\
\hline $\mathrm{K}$ & 0.88 & 50.30 & 6.78 & 10.44 & 0.70 & 16.70 & 3.81 & 2.78 \\
\hline $\mathrm{Ca}$ & 45.60 & 105.00 & 74.47 & 12.72 & 58.90 & 110.00 & 81.55 & 10.26 \\
\hline $\mathrm{Mg}$ & 1.98 & 2.15 & 2.09 & 0.03 & 0.00 & 2.18 & 2.06 & 0.35 \\
\hline $\mathrm{Fe}$ & 0.03 & 0.42 & 0.21 & 0.08 & 0.12 & 0.46 & 0.31 & 0.10 \\
\hline $\mathrm{Mn}$ & 0.04 & 1.14 & 0.36 & 0.27 & 0.02 & 0.97 & 0.31 & 0.21 \\
\hline $\mathrm{Ni}$ & 0.00 & 0.11 & 0.03 & 0.02 & 0.03 & 0.14 & 0.06 & 0.02 \\
\hline Co & 0.04 & 0.20 & 0.14 & 0.05 & 0.18 & 0.24 & 0.22 & 0.01 \\
\hline $\mathrm{Cu}$ & 1.41 & 5.87 & 4.00 & 1.15 & 5.32 & 7.35 & 6.28 & 0.53 \\
\hline $\mathrm{Cr}$ & 0.02 & 0.09 & 0.05 & 0.02 & 0.09 & 0.15 & 0.12 & 0.02 \\
\hline As & 4.18 & 75.60 & 24.67 & 15.34 & 0.34 & 74.46 & 27.81 & 19.81 \\
\hline
\end{tabular}


Table 5 PCA of groundwater characteristics in pre-monsoon

\begin{tabular}{|c|c|c|c|c|c|c|}
\hline Variables & PC1 & $\mathrm{PC} 2$ & PC3 & PC4 & PC5 & PC6 \\
\hline Temp & 0.074 & -0.055 & 0.196 & 0.163 & 0.636 & 0.092 \\
\hline $\mathrm{pH}$ & 0.152 & 0.045 & 0.656 & 0.125 & 0.093 & -0.135 \\
\hline ORP & 0.302 & -0.354 & -0.534 & -0.204 & 0.287 & -0.086 \\
\hline $\mathrm{EC}$ & 0.96 & 0.057 & -0.08 & -0.072 & -0.014 & -0.036 \\
\hline TDS & 0.959 & 0.062 & -0.086 & -0.066 & -0.017 & -0.035 \\
\hline $\mathrm{HCO}_{3}^{-}$ & -0.046 & 0.163 & 0.022 & 0.077 & 0.031 & 0.900 \\
\hline Chloride & 0.126 & 0.69 & 0.115 & -0.073 & -0.453 & 0.093 \\
\hline $\mathrm{NO}_{3}^{-}$ & 0.375 & -0.106 & 0.153 & 0.152 & -0.727 & 0.104 \\
\hline $\mathrm{NH}_{4}^{+}$ & -0.177 & -0.036 & 0.292 & 0.825 & 0.051 & -0.185 \\
\hline $\mathrm{SO}_{4}^{2-}$ & 0.791 & 0.06 & 0.3 & -0.18 & -0.091 & 0.248 \\
\hline $\mathrm{PO}_{4}^{3-}$ & -0.073 & -0.233 & -0.395 & 0.654 & 0.112 & 0.408 \\
\hline $\mathrm{Na}$ & 0.777 & 0.096 & 0.399 & 0.068 & -0.133 & 0.209 \\
\hline K & 0.644 & 0.052 & 0.506 & -0.094 & -0.36 & 0.23 \\
\hline $\mathrm{Ca}$ & 0.796 & 0.137 & 0.155 & 0.012 & 0.129 & -0.438 \\
\hline $\mathrm{Mg}$ & 0.772 & 0.082 & -0.056 & -0.128 & 0.039 & -0.207 \\
\hline $\mathrm{Fe}$ & 0.095 & 0.349 & 0.033 & 0.385 & 0.391 & 0.32 \\
\hline $\mathrm{Mn}$ & -0.049 & 0.469 & -0.135 & 0.215 & -0.367 & 0.079 \\
\hline $\mathrm{Ni}$ & 0.152 & 0.372 & 0.701 & -0.148 & 0.293 & 0.165 \\
\hline Co & 0.168 & 0.93 & 0.187 & -0.032 & 0.049 & 0.088 \\
\hline $\mathrm{Cu}$ & 0.045 & 0.937 & 0.048 & 0.011 & 0.08 & 0.065 \\
\hline $\mathrm{Cr}$ & 0.12 & 0.892 & 0.218 & 0.013 & 0.127 & -0.025 \\
\hline As & -0.221 & 0.332 & 0.01 & 0.641 & -0.135 & 0.445 \\
\hline Eigen values & 6.04 & 4.082 & 2.082 & 1.818 & 1.564 & 1.19 \\
\hline$\%$ of variance & 27.453 & 18.557 & 9.462 & 8.262 & 7.109 & 5.408 \\
\hline Cumulative $\%$ & 27.453 & 46.009 & 55.472 & 63.734 & 70.843 & 76.251 \\
\hline
\end{tabular}

Bold values in represent significant contribution by a particluar variable
2017). A positive correlation of arsenic concentration with copper concentration demonstrates anthropogenic contamination of groundwater ((Chatterjee and Mukherjee 1999). A positive correlation of chloride concentration with sulfate concentration suggests the mixing of water from different aquifer systems (Saleh et al. 1999).

\section{Principal component analysis (PCA)}

Principal component analysis (PCA) was performed for a total of 22 different factors. Six and seven major principal components (PCs) were obtained from PCA analysis in the pre-monsoon and monsoon seasons, respectively. The scree plot demonstrates that the slope for an eigenvalue has been changed after component numbers six and seven for premonsoon and monsoon season, respectively. Only eigenvalue greater than one has been taken into account for principal component analysis (PCA). They altogether accounted for 76.25 and $78.52 \%$ of total variations in the pre-monsoon and monsoon seasons, respectively. Rotated values for each component for the pre-monsoon and monsoon seasons are shown in Tables 4 and 5. PC1 explained $27.45 \%$ of the total variance observed in the pre-monsoon season. In PC1, a strong positive loading is experienced due to electrical conductivity, total dissolved solids, sulfate, sodium, potassium, calcium and magnesium concentrations. The presence of these substances in groundwater may be due to the weathering of rocky mineral substances.

Principal component 2 (PC2) represented $18.56 \%$ of the total variance explained. Positive loading is being exerted by chloride, cobalt, copper, and chromium concentrations. The sources of these ions may be industrial. The PC 3 contributed 
Table 6 PCA of groundwater characteristics in monsoon

\begin{tabular}{|c|c|c|c|c|c|c|c|}
\hline Variables & $\mathrm{PC} 1$ & PC2 & PC3 & PC4 & PC5 & PC6 & PC7 \\
\hline Temp & -0.113 & -0.319 & -0.04 & 0.766 & -0.055 & -0.122 & 0.117 \\
\hline $\mathrm{pH}$ & -0.158 & 0.109 & 0.134 & -0.063 & 0.157 & 0.854 & 0.144 \\
\hline ORP & 0.183 & -0.854 & 0.195 & 0.002 & -0.115 & -0.196 & -0.012 \\
\hline $\mathrm{EC}$ & 0.955 & -0.065 & 0.077 & 0.043 & 0.009 & 0.173 & 0.034 \\
\hline TDS & 0.954 & -0.066 & 0.079 & 0.043 & 0.01 & 0.176 & 0.033 \\
\hline $\mathrm{HCO}_{3}^{-}$ & -0.032 & 0.515 & 0.205 & 0.037 & -0.429 & -0.318 & 0.119 \\
\hline $\mathrm{Cl}^{-}$ & 0.027 & -0.027 & -0.112 & 0.132 & -0.127 & 0.05 & 0.86 \\
\hline $\mathrm{NO}_{3}^{-}$ & 0.782 & -0.119 & 0.294 & -0.115 & -0.006 & -0.107 & -0.191 \\
\hline $\mathrm{NH}_{4}^{+}$ & -0.252 & 0.04 & -0.217 & -0.427 & 0.328 & -0.468 & 0.241 \\
\hline $\mathrm{SO}_{4}{ }^{2-}$ & 0.761 & -0.09 & 0.165 & -0.151 & 0.135 & -0.038 & 0.221 \\
\hline $\mathrm{PO}_{4}{ }^{3-}$ & -0.105 & 0.606 & -0.033 & $\mathbf{0 . 5 7 7}$ & -0.222 & 0.088 & -0.181 \\
\hline $\mathrm{Na}$ & 0.778 & 0.086 & 0.11 & 0.252 & 0.18 & -0.005 & -0.033 \\
\hline K & 0.146 & 0.226 & 0.435 & 0.613 & 0.329 & -0.191 & 0.068 \\
\hline $\mathrm{Ca}$ & 0.817 & -0.133 & -0.189 & -0.001 & -0.112 & -0.275 & 0.059 \\
\hline $\mathrm{Mg}$ & 0.072 & -0.099 & 0.178 & 0.109 & -0.777 & -0.055 & 0.095 \\
\hline $\mathrm{Fe}$ & -0.742 & 0.3 & 0.189 & -0.14 & 0.084 & 0.145 & 0.077 \\
\hline $\mathrm{Mn}$ & 0.073 & 0.393 & 0.401 & -0.193 & 0.011 & 0.103 & 0.468 \\
\hline $\mathrm{Ni}$ & 0.424 & 0.033 & 0.335 & 0.158 & 0.666 & 0.054 & -0.035 \\
\hline Co & 0.302 & 0.088 & 0.41 & 0.674 & -0.04 & 0.361 & 0.09 \\
\hline $\mathrm{Cu}$ & -0.067 & -0.02 & 0.918 & 0.035 & -0.12 & 0.059 & -0.03 \\
\hline $\mathrm{Cr}$ & 0.319 & 0.08 & 0.794 & 0.324 & 0.025 & 0.198 & -0.082 \\
\hline As & -0.244 & 0.844 & 0.227 & -0.148 & 0.196 & -0.043 & 0.049 \\
\hline Eigen values & 6.023 & 3.551 & 2.17 & 1.643 & 1.475 & 1.281 & 1.133 \\
\hline$\%$ of variance & 27.376 & 16.14 & 9.863 & 7.466 & 6.706 & 5.822 & 5.151 \\
\hline Cumulative \% & 27.376 & 43.516 & 53.378 & 60.845 & 67.551 & 73.373 & 78.524 \\
\hline
\end{tabular}

Bold values in represent significant contribution by a particluar variable
Table 7 Comparison of principal components during the pre-monsoon and monsoon seasons

\begin{tabular}{|c|c|c|}
\hline PCs & Pre-monsoon & Monsoon \\
\hline PC1 & $\begin{array}{l}\mathrm{EC}, \mathrm{TDS}, \mathrm{SO}_{4}{ }^{2-}, \mathrm{Na} \text {, } \\
\mathrm{K}, \mathrm{Ca}, \mathrm{Mg}\end{array}$ & $\mathrm{EC}, \mathrm{TDS}, \mathrm{NO}_{3}{ }^{-}, \mathrm{SO}_{4}{ }^{2-}, \mathrm{Na}, \mathrm{Ca}, \mathrm{Fe}$ \\
\hline $\mathrm{PC} 2$ & $\mathrm{Co}, \mathrm{Cu}, \mathrm{Cr}, \mathrm{Cl}^{-}$ & $\mathrm{ORP}, \mathrm{HCO}_{3}{ }^{-}, \mathrm{PO}_{4}{ }^{3-}$, As \\
\hline PC3 & $\mathrm{pH}, \mathrm{K}, \mathrm{Ni}, \mathrm{ORP}$ & $\mathrm{Cu}, \mathrm{Cr}$ \\
\hline PC4 & $\mathrm{NH}_{4}^{+}, \mathrm{PO}_{4}{ }^{3-}, \mathrm{As}$, & Temp, $\mathrm{PO}_{4}{ }^{3-}, \mathrm{K}, \mathrm{Co}$ \\
\hline PC5 & Temp, $\mathrm{NO}_{3}^{-}$ & $\mathrm{Mg}, \mathrm{Ni}$ \\
\hline PC6 & $\mathrm{HCO}_{3}^{-}$ & $\mathrm{pH}$ \\
\hline PC7 & Nil & $\mathrm{Cl}^{-}$ \\
\hline
\end{tabular}

9.46\% of the total variance. PC3 showed positive loadings contributed by $\mathrm{pH}$, potassium and nickel concentrations. However, negative loading was also displayed by oxidation reduction potential. PC4 accounted for $8.26 \%$ of total variation in groundwater quality and represented by ammonium, phosphate and arsenic concentrations. For PC5, a total of
$7.11 \%$ variance was contributed by temperature and nitrate concentration. However, nitrate concentrations showed a negative loading in PC5. A strong positive loading was observed by bicarbonate concentration in PC6. It represented $5.41 \%$ of total variance in groundwater hydrochemistry. PCA analysis revealed that there is no more difference in groundwater quality/chemistry between pre-monsoon and monsoon samples although arsenic, which was loaded into PC4 in the pre-monsoon samples, was shifted into $\mathrm{PC} 2$ in monsoon samples (Tables 6, 7, 8 and 9).

In the pre-monsoon samples, $55.47 \%$ variance is explained by first three PCs, while $53.38 \%$ of the total variance is contributed by the first three PCs in monsoon samples.

\section{Hierarchical cluster analysis (HCA)}

For cluster analysis, Ward's method using squared Euclidean distance was applied. Squared Euclidean distance has 
Table 8 Sodium adsorption ratio (SAR) and percent sodium $\left(\% \mathrm{Na}^{+}\right)$ of the pre-monsoon and monsoon samples

\begin{tabular}{|c|c|c|c|c|}
\hline Sites & $\begin{array}{l}\text { Pre-monsoon } \\
\text { SAR value }\end{array}$ & $\begin{array}{l}\text { Monsoon } \\
\text { SAR value }\end{array}$ & $\begin{array}{l}\text { Pre-mon- } \\
\text { soon } \% \mathrm{Na}\end{array}$ & Monsoon $\% \mathrm{Na}$ \\
\hline 1 & 0.988 & 0.164 & 34.304 & 32.4 \\
\hline 2 & 0.905 & 0.15 & 32.831 & 30.606 \\
\hline 3 & 0.936 & 0.171 & 35.149 & 33.899 \\
\hline 4 & 0.958 & 0.17 & 32.777 & 30.511 \\
\hline 5 & 0.99 & 0.158 & 32.929 & 32.28 \\
\hline 6 & 1.112 & 0.267 & 36.798 & 44.575 \\
\hline 7 & 1.041 & 0.173 & 34.234 & 32.152 \\
\hline 8 & 0.955 & 0.162 & 33.812 & 32.541 \\
\hline 9 & 1.008 & 0.168 & 35.26 & 33.52 \\
\hline 10 & 1.001 & 0.235 & 33.455 & 43.653 \\
\hline 11 & 0.942 & 0.201 & 32.039 & 37.893 \\
\hline 12 & 1.198 & 0.252 & 43.971 & 43.192 \\
\hline 13 & 0.937 & 0.2 & 33.616 & 38.354 \\
\hline 14 & 0.732 & 0.205 & 31.16 & 37.799 \\
\hline 15 & 0.614 & 0.177 & 25.102 & 33.755 \\
\hline 16 & 1.125 & 0.195 & 41.607 & 34.717 \\
\hline 17 & 0.992 & 0.204 & 35.665 & 35.175 \\
\hline 18 & 0.871 & 0.187 & 32.674 & 39.403 \\
\hline 19 & 0.888 & 0.29 & 32.873 & 44.252 \\
\hline 20 & 0.88 & 0.193 & 31.324 & 35.454 \\
\hline 21 & 0.83 & 0.279 & 30.121 & 44.389 \\
\hline 22 & 1.017 & 0.203 & 36.793 & 40.76 \\
\hline 23 & 1.427 & 0.299 & 45.812 & 48.284 \\
\hline 24 & 0.932 & 0.286 & 33.971 & 43.488 \\
\hline 25 & 1.375 & 0.156 & 41.374 & 37.335 \\
\hline 26 & 1.144 & 0.252 & 41.245 & 41.276 \\
\hline 27 & 1.081 & 0.331 & 37.512 & 48.406 \\
\hline 28 & 1.502 & 0.175 & 47.995 & 38.319 \\
\hline 29 & 0.977 & 0.215 & 35.289 & 36.484 \\
\hline 30 & 1.093 & 0.176 & 38.27 & 37.978 \\
\hline 31 & 1.075 & 0.178 & 39.131 & 38.941 \\
\hline 32 & 0.952 & 0.17 & 29.78 & 41.024 \\
\hline 33 & 0.934 & 0.326 & 29.259 & 45.655 \\
\hline 34 & 1.027 & 0.303 & 36.218 & 42.899 \\
\hline 35 & 0.994 & 0.31 & 32.415 & 40.333 \\
\hline 36 & 0.977 & 0.265 & 32.316 & 48.728 \\
\hline
\end{tabular}

already been used for cluster analysis (Fovell and Fovell 1993; Shrestha and Kazama 2007; Yadav et al. 2014; Magesh et al. 2017; Devi and Yadav 2018; Behera and Das 2018). Cluster analysis using Ward's method gives most meaningful results (Vega et al. 1998; Sharma et al. 2017; Behera and Das 2018). The result of cluster analysis is demonstrated in the form of a dendrogram (tree-shaped structure). At distance 25 , both the pre-monsoon and monsoon variables cluster into two major distinct groups. The first cluster in the pre-monsoon season is represented by $\mathrm{Mg}^{2+}, \mathrm{K}^{+}, \mathrm{SO}_{4}{ }^{2-}$, TDS concentrations, and EC. These variables also show higher loadings in PC1 indicating their entry into groundwater system through the natural process of rock weathering (Subyani and Ahmadi 2010; Ishaku et al. 2012; Yadav et al. 2014; Gopinath et al. 2018). This cluster is also contributed by the variables like $\mathrm{Ni}, \mathrm{Cr}, \mathrm{Cu}, \mathrm{HCO}_{3}{ }^{-}, \mathrm{Co}, \mathrm{Mn}, \mathrm{PO}_{4}{ }^{3-}$ and $\mathrm{NO}_{3}{ }^{-}$concentrations most of which may be of industrial in origin. However, large agricultural inputs of fertilizers may also be possible sources of ions like $\mathrm{NO}_{3}{ }^{-}$and $\mathrm{PO}_{4}{ }^{3-}$. The second cluster is a group of three variables showing similarity between $\mathrm{Na}^{+}, \mathrm{Ca}^{2+}$, and $\mathrm{Cl}^{-}$concentrations. Interestingly, the variables of the first and second cluster in the monsoon season are observed to be almost similar to the variables of the first and second clusters present in the pre-monsoon season indicating a similar hydrogeochemistry of groundwater governed by similar types of variables.

\section{Conclusions}

Arsenic concentration together with that of other metals did not show a significant variation in the pre-monsoon and monsoon seasons. The results of the study strengthen and favor the theory of reductive dissolution of arsenic as 
Table 9 Status of groundwater characteristics in Ballia district, Uttar Pradesh, on the basis of TDS, EC, percent sodium (\% $\mathrm{Na}$ ) and sodium absorption ratio (SAR) for agricultural irrigation purposes

\begin{tabular}{|c|c|c|c|}
\hline Classification criteria & Water class & $\%$ PM (number) & $\% \mathrm{M}$ (number) \\
\hline \multicolumn{4}{|l|}{$\operatorname{TDS}\left(\mathrm{mg} \mathrm{L}^{-1}\right)$} \\
\hline$<1000$ & Satisfactory & $100(36)$ & $100(36)$ \\
\hline $1000-2000$ & Fair & 0 & 0 \\
\hline$>2000$ & Inferior & 0 & 0 \\
\hline \multicolumn{4}{|l|}{ Salinity hazard class } \\
\hline $\mathrm{C} 1$ (low): EC100-250 $\mu \mathrm{S} \mathrm{cm}^{-1}$ & Excellent & 0 & 0 \\
\hline $\mathrm{C} 2$ (medium): EC $250-750 \mu \mathrm{S} \mathrm{cm}-1$ & Good & $86.11(31)$ & $63.89(23)$ \\
\hline C3 (high): EC $750-2250 \mu \mathrm{S} \mathrm{cm}-1$ & Doubtful & $13.89(5)$ & $36.11(13)$ \\
\hline $\mathrm{C} 4$ and $\mathrm{C} 5$ (very high): $\mathrm{EC}>2250 \mu \mathrm{S} \mathrm{cm}^{-1}$ & Unsuitable & 0 & 0 \\
\hline \multicolumn{4}{|l|}{ Percent sodium $(\% \mathrm{Na})$} \\
\hline$<20$ & Excellent & 0 & 0 \\
\hline $20-40$ & Good & $83.33(30)$ & $58.33(21)$ \\
\hline $40-60$ & Permissible & $16.67(6)$ & $41.67(15)$ \\
\hline $60-80$ & Doubtful & 0 & 0 \\
\hline$>80$ & Unsuitable & 0 & 0 \\
\hline \multicolumn{4}{|l|}{ Sodium hazard class } \\
\hline S1 (low): SAR 0-10 & Excellent & $100(36)$ & $100(36)$ \\
\hline S2 (medium): SAR $10-18$ & Good & 0 & 0 \\
\hline S3 (high): SAR 18-26 & Doubtful & 0 & 0 \\
\hline S4 and S5 (very high): SAR > 26 & Unsuitable & 0 & 0 \\
\hline
\end{tabular}

revealed by positive correlations between arsenic and iron and manganese concentrations.

Acknowledgements The authors are thankful to the head, Department of Botany, Banaras Hindu University, for providing necessary facilities. The financial support provided by UGC-RFSMS (F. No. 5-106/2007), New Delhi, is thankfully acknowledged.

Open Access This article is distributed under the terms of the Creative Commons Attribution 4.0 International License (http://creativeco mmons.org/licenses/by/4.0/), which permits unrestricted use, distribution, and reproduction in any medium, provided you give appropriate credit to the original author(s) and the source, provide a link to the Creative Commons license, and indicate if changes were made.

\section{References}

Acharyya SK, Chakraborty P, Lahiri S, Raymahashay BC, Guha S, Bhowmik A (1999) Arsenic poisoning in the Ganges delta. Nature 401:545-547

Acharyya SK, Lahiri S, Raymahashay BC, Bhowmik A (2000) Arsenic toxicity of groundwater in parts of the Bengal basin in India and Bangladesh: the role of Quaternary stratigraphy and Holocene sea-level fluctuation. Environ Geol 39:1127-1137

Adams S, Titus R, Pietersenb K, Tredouxc G, Harris C (2001) Hydrochemical characteristics of aquifers near Sutherland in the Western Karoo. J Hydrol 241:91-103

Ahada CP, Suthar S (2017) Hydrochemistry of groundwater in North Rajasthan, India: chemical and multivariate analysis. Environ Earth Sci 76(5):203
Aher KR (2017) Delineation of groundwater quality for drinking and irrigation purposes: a case study of Bori Nala watershed, district Aurangabad, Maharashtra, India. J Appl Geochem 19(3):321

Alam MO, Shaikh WA, Chakraborty S, Avishek K, Bhattacharya T (2016) Groundwater arsenic contamination and potential health risk assessment of Gangetic Plains of Jharkhand, India. Expo Health 8(1):125-142

Ali I, Rahman A, Khan TA, Alam SD, Khan J (2012) Recent trends of arsenic contamination in groundwater of Ballia district, Uttar Pradesh, India. Gazi Univ J Sci 25:853-861

Andrade EM, Palacio HAQ, Souza IH, Leao RA, Guerreiro MJ (2008) Land use effects in groundwater composition of an alluvial aquifer (Trussu River, Brazil) by multivariate techniques. Environ Res 106:170-177

Ayotte JD, Szabo Z, Focazio J, Eberts SM (2011) Effects of humaninduced alteration of groundwater flow on concentrations of naturally-occurring trace elements at water-supply wells. Appl Geochem 26:747-762

Behera B, Das M (2018) Application of multivariate statistical techniques for the characterization of groundwater quality of Bacheli and Kirandul area, Dantewada district, Chattisgarh. J Geol Soc India 91(1):76-80

Bhowmick S, Pramanik S, Singh P, Mondal P, Chatterjee D, Nriagu J (2018) Arsenic in groundwater of West Bengal, India: a review of human health risks and assessment of possible intervention options. Sci Tot Environ 612:148-169

Blick J, Kumar S, Bharati VK, Kumar S (2016) Status of arsenic contamination in potable water in Chawngte, Lawngtlai district, Mizoram. Sci Vis 16(2):74-81

Chakraborti D, Das B, Rahman MM, Chowdhury UK, Biswas B, Goswami AB, Nayak B, Pal A, Sengupta MK, Ahamed S, Hossain A, Basu G, Roychowdhury T, Chakraborty S, Alam MO, Bhattacharya T, Singh YN (2014) Arsenic accumulation in food 
crops: a potential threat in Bengal delta plain. Water Qual Expo Health 6:233-246

Chakraborti D, Rahman MM, Ahamed S, Dutta RN, Pati S, Mukherjee SC (2016) Arsenic groundwater contamination and its health effects in Patna district (capital of Bihar) in the middle Ganga plain, India. Chemosphere 152:520-529

Chakraborty S (2015) Groundwater arsenic contamination in gangetic Jharkhand, India: risk implications for human health and sustainable agriculture. World Acad Sci Eng Technol Int J Environ Ecol Eng 2(12):1

Chandra S, Saha R, Pal P (2018) Assessment of arsenic toxicity and tolerance characteristics of bean plants (Phaseolus vulgaris) exposed to different species of arsenic. J Plant Nutr 41(3):340-347

Chandrashekhar AK, Chandrasekharam D, Farooq SH (2016) Contamination and mobilization of arsenic in the soil and groundwater and its influence on the irrigated crops, Manipur Valley, India. Environ Earth Sci 75(2):142

Chatterjee A, Mukherjee A (1999) Hydrogeological investigation of ground water arsenic contamination in South Calcutta. Sci Tot Environ 225:249-262

Chauhan VS, Nickson RT, Chauhan D, Iyenga L, Sankararamakrishnan N (2009) Ground water geochemistry of Ballia district, Uttar Pradesh, India and mechanism of arsenic release. Chemosphere 75:83-91

Chidambaram S, Thilagavathi R, Thivya C, Karmegam U, Prasanna MV, Ramanathan AL, Tirumalesh K, Sasidhar P (2017) A study on the arsenic concentration in groundwater of a coastal aquifer in south-east India: an integrated approach. Environ Dev Sustain 19(3): 1015-1040

Chitradevi S, Sridhar SGD (2011) Hydrochemical characterization of groundwater in the proximity of river Noyyal, Tiruppur, South India. Indian J Sci Technol 4:1732-1736

Dar MA, Sankar K, Dar IA (2011) Major ion chemistry and hydrochemical studies of groundwater of parts of Palar river basin, Tamil Nadu, India. Environ Monit Assess 176:621-636

Das HK, Mitra AK, Sengupta PK, Hossain A, Islam F, Rabbani GH (2004) Arsenic concentrations in rice, vegetables, and fish in Bangladesh: a preliminary study. Environ Int 30:383-387

Das S, Bora SS, Yadav RNS, Barooah M (2017) A metagenomic approach to decipher the indigenous microbial communities of arsenic contaminated groundwater of Assam. Genomics Data 12:89-96

Devi NL, Yadav IC (2018) Chemometric evaluation of heavy metal pollutions in Patna region of the Ganges alluvial plain, India: implication for source apportionment and health risk assessment. Environ Geochem Health 1-16. https://doi.org/10.1007/ s10653-018-0101-4

Devic G, Djordjevic D, Sakan S (2014) Natural and anthropogenic factors affecting the groundwater quality in Serbia. Sci Tot Environ 468-469:933-942

Fovell R, Fovell MY (1993) Climate zones of the conterminous United State defined using cluster analysis. J Clim 6:2103-2135

Gao Y, Mucci A (2001) Acid base reactions, phosphate and arsenate complexation, and their competitive adsorption at the surface of goethite in $0.7 \mathrm{M} \mathrm{NaCl}$ solution. Geochim et Cosmochim Acta 65:2361-2378

Gao X, Su C, Yanxin Wang Y, Hu Q (2013) Mobility of arsenic in aquifer sediments at Datong Basin, northern China: effect of bicarbonate and phosphate. J Geochem Explor 135:93-103

Gopinath S, Srinivasamoorthy K, Vasanthavigar M, Saravanan K, Prakash R, Suma CS, Senthilnathan D (2018) Hydrochemical characteristics and salinity of groundwater in parts of Nagapattinam district of Tamil Nadu and the Union Territory of Puducherry, India. Carbonates Evaporites 33(1):1-13
Gu X, Xiao Y, Yin S, Pan X, Niu Y, Shao J, Cui Y, Zhang Q, Hao Q (2017) Natural and anthropogenic factors affecting the shallow groundwater quality in a typical irrigation area with reclaimed water, North China Plain. Environ Mon Assess 189(10):514

Gulgundi MS, Shetty A (2018) Groundwater quality assessment of urban Bengaluru using multivariate statistical techniques. Appl Water Sci 8(1):43

Guo H, Zhang B, Wang G, Shen Z (2010) Geochemical controls on arsenic and rare earth elements approximately along a groundwater flow path in the shallow aquifer of the Hetao Basin, Inner Mongolia. Chem Geol 270:117-125

Helena B, Pardo R, Vega M, Barrado E, Fernandez JM, Fernandez L (2000) Temporal evolution of groundwater composition in an alluvial aquifer (Pisuerga River, Spain) by principal component analysis. Water Res 34:807-816

Huq SMI, Joardar JC, Parvin S, Correll R, Naidu R (2006) Arsenic contamination in food-chain: transfer of arsenic into food materials through groundwater irrigation. J Health Popul Nutr 24:305-316

Hussain M, Rao TP (2014) Toxic trace element contamination in ground water of Bollaram and Patancheru, Andhra Pradesh, India. Am J Chem 4(1):1-9

Ishaku JM, Nur A, Matazu HI (2012) Interpretation of groundwater quality in Fufore, Northeastern Nigeria. Int J Earth Sci Eng $5: 373-382$

Jasmin I, Mallikarjuna P (2006) Physicochemical quality evaluation of groundwater and development of drinking water quality index for Araniar River Basin, Tamil Nadu, India. Environ Monit Assess 186:935-948

Kanel SR, Malla GB, Cho H (2013) Modeling and study of the mechanism of mobilization of arsenic contamination in the groundwater of Nepal in South Asia. Clean Technol Environ Policy 15:1077-1082

Karanth KR (1987) Groundwater assessment, development and management. Tata McGraw Hill Publishing Company Limited, New Delhi

Kashyap R, Verma KS, Uniyal SK, Bhardwaj SK (2018) Geospatial distribution of metal (loid) $\mathrm{s}$ and human health risk assessment due to intake of contaminated groundwater around an industrial hub of northern India. Environ Monitor Assess 190(3):136

Kazi TG, Arain MB, Jamali MK, Jalbani N, Afridi HI, Sarfraz RA, Baig JA, Shah AQ (2009) Assessment of water quality of polluted lake using multivariate statistical techniques: a case study. Ecotoxicol Environ Saf 72:301-309

Khanikar L, Gogoi RR, Das N, Deka JP, Das A, Kumar M, Sarma KP (2017) Groundwater appraisal of Dhekiajuli, Assam, India: an insight of agricultural suitability and arsenic enrichment. Environ Earth Sci 76(15):530

Kotti ME, Vlessidis AG, Thanasoulias NC, Evmiridis NP (2005) Assessment of river water quality in Northwestern Greece. Wat Res Manag 19:77-94

Kouras A, Katsoyiannis IA, Voutsa D (2007) Distribution of arsenic in groundwater in the area of Chalkidiki, Northern Greece. J Haz Mat 147:890-899

Kshetrimayum KS, Bajpai VN (2012) Assessment of groundwater quality for irrigation use and evolution of hydrochemical facies in the Markanda river basin, northwestern India. J Geol Soc India 79:189-198

Kumar M, Ramanathan AL, Tripathi R, Farswan S, Kumar D, Bhattacharya P (2017a) A study of trace element contamination using multivariate statistical techniques and health risk assessment in groundwater of Chhaprola Industrial Area, Gautam Buddha Nagar, Uttar Pradesh, India. Chemosphere 166:135-145

Kumar MS, Dhakate R, Yadagiri G, Reddy KS (2017b) Principal component and multivariate statistical approach for evaluation of hydrochemical characterization of fluoride-rich groundwater 
of Shaslar Vagu watershed, Nalgonda District, India. Arab J Geosci 10(4):83

Kumar S, Venkatesh AS, Singh R, Udayabhanu G, Saha D (2018) Geochemical signatures and isotopic systematics constraining dynamics of fluoride contamination in groundwater across Jamui district, Indo-Gangetic alluvial plains, India. Chemosphere 205:493-505

Kumarathilaka P, Seneweera S, Meharg A, Bundschuh J (2018) Arsenic speciation dynamics in paddy rice soil-water environment: sources, physico-chemical, and biological factors-a review. Water Res 140:403-414

Laluraj CM, Gopinath G, Dinesh Kumar PK, Seralathan P (2006) Seasonal variations in groundwater chemistry of a phreatic coastal and crystalline terrain of central Kerala, India. Environ Foren 7:335-344

Magesh NS, Chandrasekar N, Elango L (2017) Trace element concentrations in the groundwater of the Tamiraparani river basin, South India: insights from human health risk and multivariate statistical techniques. Chemosphere 185:468-479

Mavi MS, Marschner P, Chittleborough DJ, Cox JW, Sanderman J (2012) Salinity and sodicity affect soil respiration and dissolved organic matter dynamics differentially in soils varying in texture. Soil Biol Biochem 45:8-13

McArthur JM, Ravenscroft P, Safiulla S, Thirlwall MF (2001) Arsenic in groundwater: testing pollution mechanisms for sedimentary aquifers in Bangladesh. Water Resour Res 37:109-117

McKenna JE (2003) An enhanced cluster analysis program with bootstrap significance testing for ecological community analysis. Environ Model Softw 18:205-220

Naidu R, Smith E, Owens G, Bhattacharya P, Nadebaum P (2006) Extent and severity of arsenic poisoning in Bangladesh. In: Managing arsenic in the environment: from soil to human health. pp 525-540

Nelson PN, Barzegar AR, Oades JM (1997) Sodicity and clay type: influence on decomposition of added organic matter. Soil Sci Soc Am J 61:1052-1057

Niemi GJ, Devore P, Detenbeck N, Taylor D, Lima A (1990) Overview of case studies on recovery of aquatic systems from disturbance. Environ Manag 14:571-587

Noori R, Sabahi MS, Karbassi AR, Baghvand A, Zadeh HT (2010) Multivariate statistical analysis of surface water quality based on correlations and variations in the data set. Desalination 260:129-136

Ohno K, Furukawa A, Hayashi K, Kamei T, Magara Y (2005) Arsenic contamination of groundwater in Nawabganj, Bangladesh, focusing on the relationship with other metals and ions. Water Sci Technol 52:87-94

Olea RA, Raju NJ, Egozcue JJ, Pawlowsky-Glahn V, Singh S (2018) Advancements in hydrochemistry mapping: methods and application to groundwater arsenic and iron concentrations in Varanasi, Uttar Pradesh, India. Stoch Environ Res Risk Assess 32(1):241-259

Omo-Irabor OO, Olobaniyi SB, Oduyemi K, Akunna J (2008) Surface and groundwater water quality assessment using multivariate analytical methods: a case study of the Western Niger Delta, Nigeria. Phys Chem Earth 33:666-673

Patel KS, Sahu BL, Dahariya NS, Bhatia A, Patel RK, Matini L, Sracek O, Bhattacharya P (2017) Groundwater arsenic and fluoride in Rajnandgaon District, Chhattisgarh, northeastern India. Appl Water Sci 7(4):1817-1826

Purushotham D, Dharavath L, Mishra S, Kavitha S, Vinod GN (2017) Deciphering heavy metal contamination zones in parts of Nalgonda District, Telangana. J Geol Soc India 89(4):419-428

Rahman MM, Naidu R, Bhattacharya P (2009) Arsenic contamination in groundwater in the Southeast Asia Region. Environ Geochem Health 31:9-21
RamyaPriya R, Elango L (2018) Evaluation of geogenic and anthropogenic impacts on spatio-temporal variation in quality of surface water and groundwater along Cauvery River, India. Environ Earth Sci 77(1):2

Rana A, Bhardwaj SK, Thakur M, Verma S (2016) Assessment of heavy metals in surface and ground water sources under different land uses in mid-hills of Himachal Pradesh. Int J Bio-Res Stress Manag 7(3):461-465

Rao NS (2006) Seasonal variation of groundwater quality in a part of Guntur District, Andhra Pradesh, India. Environ Geol 49(3):413-429

Ravikumar P, Somashekar RK (2017) Principal component analysis and hydrochemical facies characterization to evaluate groundwater quality in Varahi river basin, Karnataka state, India. Appl Water Sci 7(2):745-755

Ravikumar P, Venkatesharaju K, Somashekar RK (2010) Major ion chemistry and hydrochemical studies of groundwater of Bangalore South Taluk, India. Environ Monit Assess 163:643-653

Reghunath R, Murthy TRS, Raghavan BR (2002) The utility of multivariate statistical techniques in hydrogeochemical studies: an example from Karnataka, India. Water Res 36:2437-2442

Rietz DN, Haynes RJ (2003) Effects of irrigation-induced salinity and sodicity on soil microbial activity. Soil Biol Biochem 35:845-854

Saleh A, Al-Ruwaih F, Shehata M (1999) Hydro-geochemical processes operating within the main aquifers of Kuwait. J Arid Environ 42:195-209

Sappa G, Ergul S, Ferranti F (2014) Water quality assessment of carbonate aquifers in southern Latium region, Central Italy: a case study for irrigation and drinking purposes. Appl Water Sci 4:115-128

Sathe SS, Mahanta C, Mishra P (2018) Simultaneous influence of indigenous microorganism along with abiotic factors controlling arsenic mobilization in Brahmaputra floodplain, India. J Cont Hydrol 213:1-14. https://doi.org/10.1016/j.jconhyd.2018.03.005

Selvaganapathi R, Vasudevan S, Balamurugan P, Nishikanth CV, Gnanachandrasamy G, Sathiyamoorthy G (2017) Evaluation of groundwater quality and water quality index in the Palacode and Pennagaram Taluks, Dharmapuri district, Tamil Nadu, India. Int J Appl Res 3(6):285-290

Selvakumar S, Chandrasekar N, Kumar G (2017) Hydrogeochemical characteristics and groundwater contamination in the rapid urban development areas of Coimbatore, India. Water Res Ind 17:26-33

Shah BA (2015) Status of groundwater arsenic contamination in the states of North-east India: a review. Indian Groundwater 5:32-37

Shah BA (2017) Groundwater arsenic contamination from parts of the Ghaghara Basin, India: influence of fluvial geomorphology and Quaternary morphostratigraphy. Appl Water Sci 7(5):2587-2595

Sharifi R, Moore F, Keshavarzi B, Badiei S (2017) Assessment of health risks of arsenic exposure via consumption of crops. Expo Health, pp 1-15

Sharma S, Kaur J, Nagpal AK, Kaur I (2016) Quantitative assessment of possible human health risk associated with consumption of arsenic contaminated groundwater and wheat grains from Ropar Wetand and its environs. Environ Monit Assess 188(9):506

Sharma S, Kaur I, Nagpal AK (2017) Assessment of arsenic content in soil, rice grains and groundwater and associated health risks in human population from Ropar wetland, India, and its vicinity. Environ Sci Pollut Res 24(23):18836-18848

Sharma SK, Yadav S, Parashar VK, Dubey P (2018) Assessment of agricultural water quality of shallow groundwater between Budhni and Chaursakhedi, North of River Narmada, District Sehore, Madhya Pradesh, India. In: Environmental pollution. Springer, Singapore, pp 403-418

Sheikh MA, Azad C, Mukherjee S, Rina K (2017) An assessment of groundwater salinization in Haryana state in India using

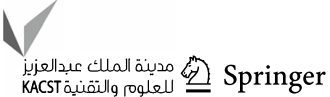


hydrochemical tools in association with GIS. Environ Earth Sci 76(13):465

Shrestha S, Kazama F (2007) Assessment of surface water quality using multivariate statistical techniques: a case study of the Fuji river basin, Japan. Environ Model Softw 22:464-475

Shrivastava A, Barla A, Singh S, Mandraha S, Bose S (2017) Arsenic contamination in agricultural soils of Bengal deltaic region of West Bengal and its higher assimilation in monsoon rice. J Hazard Mater 324:526-534

Simeonov V, Simeonova P, Tsitouridou R (2004) Chemometric quality assessment of surface waters: two case studies. Chem Eng Ecol 11:449-469

Singh KP, Malik A, Mohan D, Sinha S (2004) Multivariate statistical techniques for the evaluation of spatial and temporal variations in water quality of Gomti River (India): a case study. Water Res 38:3980-3992

Singh KP, Malik A, Sinha S (2005) Water quality assessment and apportionment of pollution sources of Gomti river (India) using multivariate statistical techniques: a case study. Analyt Chim Acta 538:355-374

Singh EJK, Gupta A, Singh NR (2013) Groundwater quality in Imphal west district, Manipur: India, with multivariate statistical analysis of data. Environ Sci Pollut Res 20:2421-2434

Singh UK, Ramanathan AL, Subramanian V (2018) Groundwater chemistry and human health risk assessment in the mining region of East Singhbhum, Jharkhand, India. Chemosphere 204:501-513

Singhal VK, Anurag GR, Kumar T (2018) Arsenic concentration in drinking and irrigation water of Ambagarh Chowki Block, Rajnandgaon (Chhattisgarh). Int J Chem Stud 6(2):733-739

Smedley PL, Kinniburgh DG (2002) A review of the sources, behaviour and distribution of arsenic in natural waters. Appl Geochem 17:517-568

Srinivas Y, Aghil TB, Oliver DH, Nair CN, Chandrasekar N (2017) Hydrochemical characteristics and quality assessment of groundwater along the Manavalakurichi coast, Tamil Nadu, India. Appl Water Sci 7(3):1429-1438

Subyani AM, Ahmadi MA (2010) Multivariate statistical analysis of groundwater quality in Wadi Ranyah, Saudi Arabia. JAKU Earth Sci 21:29-46

Thapa R, Gupta S, Reddy DV, Kaur H (2018) Comparative evaluation of water quality zonation within Dwarka River Basin, India. Hydrol Sci J 63(4):583-595

Tripathi PK (2007-2008) District brochure of Ballia district, U.P. (A.A.P.: 2007-2008), p 22. http://cgwb.gov.in/District_Profile/ UP/Ballia.pdf
UN (2006) African water development report-2006. UN-Water/Africa, Addis Ababa, p 370

Vega M, Pardo R, Barrado E, Deban L (1998) Assessment of seasonal and polluting effects on the quality of river water by exploratory data analysis. Water Res 32:3581-3592

Vodela JK, Renden JA, Lenz SD, Mchel Henney WH, Kemppainen BW (1997) Drinking water contaminants. Poult Sci 76:1474-1492

Wang YX, Shvartsev SL, Su C (2009) Genesis of arsenic/fluorideenriched soda water: a case study at Datong, northern China. Appl Geochem 24:641-649

Winkel LHE, Trang PTK, Lan VM, Stengel C, Amini M, Ha NT, Viet PH, Berg M (2011) Arsenic pollution of groundwater in Vietnam exacerbated by deep aquifer exploitation for more than a century. Proc Natl Acad Sci USA 108:1246-1251

Yadav IC, Devi NL, Mohan D, Shihua Q, Singh S (2014) Assessment of groundwater quality with special reference to arsenic in Nawalparasi district, Nepal using multivariate statistical techniques. Environ Earth Sci 72:259-273

Yadav KK, Gupta N, Kumar V, Choudhary P, Khan SA (2018) GISbased evaluation of groundwater geochemistry and statistical determination of the fate of contaminants in shallow aquifers from different functional areas of Agra city, India: levels and spatial distributions. RSC Adv 8(29):15876-15889

Yakubo BB, Yidana SM, Nti E (2009) Hydrochemical analysis of groundwater using multivariate statistical methods: the Volta region, Ghana. KSCE J Civ Eng 13:55-63

Yeung IMH (1999) Multivariate analysis of the Hong Kong Victoria Harbour water quality data. Environ Monit Assess 59:331-342

Yidana S (2010) Groundwater classification using multivariate statistical methods: Birimian basin, Ghana. J Environ Eng 136:1379-1388

Yidana SM, Bawoyobie P, Sakyi P, Fynn OF (2018) Evolutionary analysis of groundwater flow: application of multivariate statistical analysis to hydrochemical data in the Densu Basin, Ghana. J Afr Earth Sci 138:167-176

Zhao FJ, McGrath SP, Meharg AA (2010) Arsenic as a food chain contaminant: mechanisms of plant uptake and metabolism and mitigation strategies. Ann Rev Plant Biol 61:535-559

Zhao J, Fu G, Lei K, Li Y (2011) Multivariate analysis of surface water quality in the Three Gorges area of China and implications for water management. J Environ Sci 23:1460-1471

Publisher's Note Springer Nature remains neutral with regard to jurisdictional claims in published maps and institutional affiliations. 